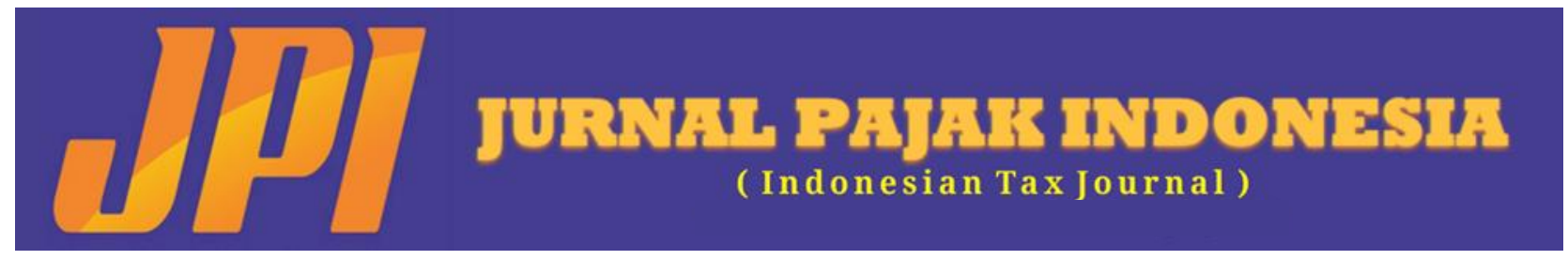

\title{
REFORMULASI PENGKREDITAN PAJAK MASUKAN PASCA OMNIBUS LAW
}

\author{
Suparna Wijaya \\ Politeknik Keuangan Negara STAN \\ Izma Awwalia Sabina Dewani \\ Politeknik Keuangan Negara STAN
}

E-Alamat Korespondensi : sprnwijaya@pknstan.ac.id

\section{INFORMASI ARTIKEL}

Diterima Pertama

[28062021]

Dinyatakan Diterima

[060172021]

KATA KUNCI:

Pengkreditan Pajak Masukan, Undang-Undang Cipta Kerja, Pajak Pertambahan Nilai, Pengusaha Kena Pajak

KLASIFIKASI JEL:

E620

\section{ABSTRAK}

Input tax crediting is one of the obligations that must be carried out by taxable person. In order to provide convenience and relief for taxable person as taxpayers, the tax authority regulates the provision through relaxation of input tax crediting in the Job Creation Law. But in the implementation of relaxation of input tax crediting still causes conflicts between taxable persons, one of which is related to input tax crediting before the business is confirmed as a taxable person. Other derivative regulations related to input tax crediting are also considered to have not reflected fairness and are considered irrelevant. The purpose of this research is to further review how the implementation of the guidelines for calculating input tax crediting before the business is confirmed as a taxable person and provide advices and ideas for the tax authority on how the regulation on input tax crediting should be in accordance with the principles and characteristics of Value Added Tax. Thus, this $r$ esearch needs to be done so that the input tax crediting regulations can be reformulated, considering the enactment of the Omnibus Law is a very appropriate momentum for the Directorate General of Taxes to improve regulations in the taxation sector.

Pengkreditan pajak masukan merupakan salah satu kewajiban yang harus dilaksanakan pengusaha kena pajak. Dalam rangka memberikan kemudahan dan keringanan bagi PKP (Pengusaha Kena Pajak) selaku wajib pajak, otoritas pajak mengatur ketentuan tersebut melalui Relaksasi Pengkreditan Pajak Masukan di dalam Undang-Undang Cipta Kerja. Namun di dalam pengimplementasiannya relaksasi pengkreditan pajak masukan masih menimbulkan konflik antar pengusaha kena pajak, salah satunya terkait pengkreditan pajak masukan sebelum pengusaha dikukuhkan sebagai pengusaha kena pajak. Peraturan turunan lain terkait pengkreditan pajak masukan juga dirasa belum mencerminkan keadilan dan dianggap sudah tidak relevan. Tujuan penelitian ini adalah untuk meninjau lebih lanjut bagaimana pelaksanaan Pedoman Penghitungan Pengkreditan Pajak Masukan sebelum pengusaha dikukuhkan sebagai PKP serta memberikan saran dan masukan bagi otoritas pajak bagaimana seharusnya peraturan mengenai pengkreditan pajak masukan agar sesuai dengan prinsip dan karakteristik Pajak Pertambahan Nilai. Dengan demikian, penelitian ini perlu dilakukan agar nantinya peraturan pengkreditan pajak masukan dapat direformulasi. mengingat disahkannya Omnibus Law merupakan momentum yang sangat tepat bagi Direktorat Jenderal Pajak untuk memperbaiki regulasi di sektor perpajakan. 


\section{PENDAHULUAN}

\subsection{Latar Belakang}

Omnibus Law, atau biasa disebut dengan konsep

Omnibus Bill, merupakan sebuah metode atau teknik untuk menyelaraskan dan mengintegrasikan perumusan peraturan perundang-undangan yang mana undang-undang tersebut pertama kali dibahas di Amerika Serikat pada tahun 1840. Konsep Omnibus sejatinya diadopsi oleh negara-negara yang menganut sistem hukum common law, berlawanan dengan sistem hukum Indonesia yang mengadopsi civil law.

Black (1968, dikutip dalam Prabowo et al., 2020) menyatakan definisi Omnibus Bill bahwa dalam praktik legislatif terdapat sebuah rancangan undang-undang yang mengandung dua atau lebih hal independen dan menggabungkan sejumlah subjek yang berbeda dalam satu undang-undang yang mana ketentuan-ketentuan di dalamnya harus dipatuhi. Dari pernyataan tersebut dapat disimpulkan bahwa Omnibus Law merupakan suatu konsep atau metode yang dilakukan pemerintah untuk tujuan pembuatan regulasi dengan cara menggabungkan, menambah, mengamandemen, hingga menghapus beberapa peraturan yang substansinya berbeda dalam payung hukum yang sama.

Nurhanisah \& Devina (2020) menjelaskan, dalam kurun waktu 2014 - 2019 Indonesia tercatat telah mengeluarkan sekitar 10.180 peraturan. UU Cipta Kerja juga menyatakan bahwa saat ini terdapat 4.451 peraturan Pemerintah Pusat dan 15.965 peraturan Pemerintah Daerah. Hal inilah yang menyebabkan Indonesia mulai merancang untuk membuat konsep Omnibus Law dengan tujuan merampingkan regulasi, menyederhanakan peraturan, dan mengatasi tumpang tindih regulasi.

Peraturan yang ada di Indonesia sudah termasuk ke kategori hyper dan overlapping regulasi (Anggraeni \& Rachman, 2020). Lebih lanjut, Omnibus Law selain untuk memperbaiki regulasi di Indonesia juga memiliki tujuan lain yang lebih spesifik. Dalam penyusunan Omnibus Law, pemerintah Indonesia akan membahas tiga undang-undang besar, yaitu Undang-Undang Cipta Kerja, Undang-Undang Pemberdayaan UMKM, dan Undang-Undang Perpajakan (Yuliawati, 2020).

Berdasarkan Center for Indonesia Taxation Analysis (2020) yang membahas mengenai klaster perpajakan dalam UU Cipta Kerja, peraturan Perpajakan dalam Omnibus Law bertujuan untuk meningkatkan pembangunan nasional dengan cara memberikan kemudahan berusaha bagi masyarakat, untuk PPN sendiri berikut beberapa kebijakan dari DJP dan manfaat yang dapat diperoleh para pelaku usaha dalam rangka meningkatkan perekonomian nasional, meningkatkan pendanaan investasi, mendorong kepatuhan wajib pajak dan wajib bayar secara sukarela, dan menciptakan keadilan iklim berusaha di dalam negeri.

Omnibus Law terdiri dari kumpulan RUU (Rancangan Undang-Undang) tentang Cipta Lapangan
Kerja, Ketentuan dan Fasilitas Perpajakan untuk Penguatan Perekonomian, serta Pengembangan dan Penguatan Sektor Keuangan (Idris, 2020). Satu dari ketiga undang-undang tersebut telah disahkan, yaitu Undang-Undang tentang Cipta Lapangan Kerja atau biasa disebut UU Cipta Kerja yang mana UndangUndang tentang Perpajakan dilebur ke dalam undangundang tersebut. UU Cipta Kerja, yang telah disahkan pada tanggal 5 Oktober 2020 dan mulai diberlakukan pada tanggal 2 November 2020, memuat empat kebijakan baru mengenai peraturan perpajakan, salah satunya Pajak Pertambahan Nilai (PPN).

Menanggapi reformasi perpajakan, pemerintah juga berfokus ke penerimaan PPN dan Pajak Penjualan Barang Mewah (PPnBM) karena terdapat potensi penerimaan dari kedua pajak tersebut seiring dengan meningkatnya tingkat konsumsi masyarakat saat ini. Pada tahun 2018, proporsi penerimaan PPN dan PPnBM hanya mencapai 40,91\% dan menurun pada tahun 2019 menjadi $39,89 \%$, hal tersebut menunjukkan penerimaan PPN dan PPnBM belum teroptimalisasi dengan baik. Perubahan UU PPN dalam UU Cipta Kerja merupakan strategi yang diberikan pemerintah untuk mendorong angka pertumbuhan ekonomi melalui pemberian kemudahan pajak dan sebagai peluang untuk meningkatkan jumlah wajib pajak baru. Salah satu komponen penting PPN adalah pengkreditan Pajak Masukan dan Pajak Keluaran untuk memperhitungkan pajak terutang. Maka dari itu, perlu ditelusuri dan diperbaiki dalam rangka meningkatkan penerimaan PPN.

Pada umumnya PPN bersifat netral, yakni PPN dikenakan pada setiap konsumen akhir. Pengusaha Kena Pajak (PKP) dalam melaksanakan kewajiban perpajakannya bertindak sebagai pemungut PPN atas transaksi barang dan/atau jasa dengan menyetor dan melapor pajak, serta mempunyai hak untuk menerapkan mekanisme pengkreditan Pajak Masukan dengan Pajak Keluaran dalam suatu masa pajak yang sama sesuai dengan undang-undang yang berlaku guna mengetahui pajak terutang. Mengacu pada konsep netralitas, dengan melakukan pengkreditan Pajak Masukan, PKP tidak menanggung beban PPN.

Berdasarkan Pasal 9 ayat (8) huruf (a) dan (d) Undang-Undang Nomor 8 Tahun 1984 jo UndangUndang Nomor 42 Tahun 2009 tentang Pajak Pertambahan Nilai Barang dan Jasa dan Pajak Penjualan atas Barang Mewah, salah satu kriteria Pajak Masukan yang tidak dapat dikreditkan adalah perolehan Barang Kena Pajak (BKP) atau Jasa Kena Pajak (JKP), dan pengusaha yang melakukan pemanfaatan atas BKP tidak berwujud atau JKP dari luar daerah pabean sebelum pengusaha dikukuhkan sebagai PKP. Pasalnya, di dalam UU Cipta Kerja pasal 112 atas perubahan UU Nomor 42 Tahun 2009 dalam pasal yang sama, pemerintah menghapuskan ketentuan tersebut. Dengan dihapuskannya beberapa ketentuan dalam pasal di atas menimbulkan persepsi dari masyarakat bahwa setiap 
pengusaha boleh mengkreditkan Pajak Masukan meskipun pengusaha tersebut belum dikukuhkan sebagai PKP.

Terkait hal tersebut, pihak DJP menerapkan skema deemed Pajak Masukan yang telah diatur di Peraturan Menteri Keuangan (PMK) 74/PMK.03/2010. Dalam PMK tersebut dijelaskan bahwa Pajak Masukan dapat dikreditkan oleh PKP, dengan syarat PKP melakukan penyerahan atas barang dan/atau jasa yang terutang pajak saja. Hal tersebut sesuai dengan pernyataan "Generally, a registered (or taxable) person can claim credit for input tax on acquisitions (import and domestic purchases) of goods and services used in connection with taxable supplies." (Schenk \& Oldman, 2007). PKP yang menerapkan skema deemed Pajak Masukan memiliki syarat dan kriteria tertentu yang mana dalam menghitung pengkreditan Pajak Masukannya berbeda dengan PKP pada umumnya.

Salah satu kebijakan perpajakan di UU Cipta Kerja adalah diberikannya Relaksasi Pengkreditan Pajak Masukan, relaksasi ini dianggap sebagai sebuah insentif bagi wajib pajak karena meringankan beban wajib pajak dalam dunia usaha. Di sisi lain, terdapat pro dan kontra mengenai kebijakan Relaksasi Pengkreditan Pajak Masukan yang ada di UU Cipta Kerja karena bertabrakan dengan ketentuan Peraturan Menteri Keuangan 74/PMK.03/2010.

Setelah dianalisis lebih lanjut, dalam PMK 74/PMK.03/2010 juga tidak menjabarkan secara jelas mengenai definisi peredaran usaha bagi PKP. Sejatinya, dalam pelaksanaan pengkreditan Pajak Masukan dengan Pajak Keluaran, didasari oleh jumlah peredaran usaha. Pada kenyataannya, PKP menghitung total peredaran usaha dengan mencantumkan semua penghasilannya dari seluruh transaksi atas penyerahan barang dan jasa. Hal tersebut didukung juga pada pernyataan di lampiran PER-45/PJ/2010 sebagaimana diubah dalam PER-10/PJ/2013 yang menjelaskan bahwa PKP harus memperhitungkan seluruh penyerahan atas barang dan jasa dalam pengisian SPT Masa PPN 1111 DM.

UU PPN menerapkan prinsip negative list, yaitu barang dan jasa yang tercantum di dalam undangundang tersebut termasuk yang dikecualikan dari PPN, sehingga barang dan jasa yang tidak termasuk ke dalam UU PPN dianggap sebagai BKP dan JKP. Terdapat pula kondisi lain ketika barang dan jasa tidak dikenakan PPN, yaitu saat terjadinya penyerahan ekspor dan pemberian fasilitas tidak dipungut dan dibebaskan dari PPN.

Melihat tidak adanya kejelasan mengenai definisi barang dan jasa apa saja yang boleh diperhitungkan di dalam jumlah peredaran usaha, serta ketentuan mengenai penghitungan penyerahan barang dan jasa pada SPT Masa PPN 1111 DM yang bersinggungan dengan UU PPN, maka untuk menerapkan deemed Pajak Masukan akan menimbulkan kesalahan, yakni PKP memungut pajak atas barang dan jasa yang seharusnya tidak dipungut dan mencantumkan komponen penyerahan yang seharusnya tidak terutang PPN dalam penghitungan pajak keluaran.

Penulis belum sekalipun menemukan penelitian dengan topik pengkreditan Pajak Masukan pada UU Cipta Kerja. Selanjutnya, dikarenakan terdapat perubahan dan perbedaan yang signifikan antara UU Nomor 42 Tahun 2009 dengan perubahannya yang termaktub di UU Cipta Kerja, penulis tertarik untuk melakukan penelitian ini sebagai sumbangan kajian untuk mengetahui bagaimana ketentuan yang mengatur Pedoman Pengkreditan Pajak Masukan sebelum pengusaha dikukuhkan sebagai Pengusaha Kena Pajak, mengidentifikasi konflik antara PMK 74/PMK.03/2010 dengan peraturan perundangundangan lainnya yang berkaitan dengan pengkreditan Pajak Masukan, menjelaskan mekanisme pengimplementasian Pedoman Penghitungan Pengkreditan Pajak Masukan sebelum pengusaha dikukuhkan sebagai Pengusaha Kena Pajak, mengetahui alasan mengapa format SPT Masa PPN 1111 DM memiliki perbedaan dengan format SPT Masa PPN 1111, dan menjelaskan apakah strategi Relaksasi Pengkreditan Pajak Masukan merupakan kebijakan yang tepat terhadap Sektor Perpajakan Indonesia.

\section{METODOLOGI}

Metode penelitian yang digunakan penulis untuk memperoleh data dan informasi adalah metode kualitatif yang menghasilkan data primer dan sekunder. Data sekunder berupa dokumentasi dengan cara mengumpulkan dan mempelajari literatur terkait seperti buku, jurnal, undang-undang, peraturan, dan sumber lainnya yang bertujuan untuk memahami konsep dasar dan mendapatkan informasi tambahan mengenai masalah yang akan dibahas.

Data primer dilakukan dengan wawancara dengan narasumber petugas Direktorat Jenderal Pajak, Dosen Politeknik Keuangan Negara STAN, serta Akademisi, Peneliti, dan Praktisi Perpajakan. Jumlah narasumber terdiri dari tiga orang sehingga dapat ditelusuri sudut pandang dan pendapat yang berbeda dari beberapa pihak. Penulis melakukan wawancara kepada Bapak Muhammad Ilham Fakhruli yang merupakan pegawai Direktorat Peraturan Perpajakan I seksi Peraturan PPN Perdagangan I, Tn ABC (nama disamarkan karena tidak memperkenankan penulis untuk mempublikasikan identitas) yang bekerja sebagai Akademisi, Peneliti, dan Praktisi Perpajakan, dan Bapak Rachmad Utomo selaku Dosen Pajak Pertambahan Nilai Politeknik Keuangan Negara STAN.

Triangulasi digunakan untuk membandingkan hasil wawancara dari beberapa narasumber dengan ketentuan peraturan perpajakan yang ada dalam rangka membuktikan kebenaran dari informasi yang telah disampaikan.

\section{LANDASAN TEORI}

\subsection{Reformasi Peraturan Perpajakan}

Reformasi pajak berkaitan erat dengan peningkatan kesejahteraan dengan membuat 
perubahan marginal dalam desain struktur pajak (Jha, 2010). Reformasi pajak mencakup kebijakan kenaikan dan penurunan tarif pajak, perubahan pada ketentuan basis perpajakan, pengenalan peraturan perpajakan baru dan penghapusan peraturan perpajakan lama, serta perubahan dalam bauran pajak.

Reformasi pajak juga bertujuan untuk menciptakan sistem pajak yang efektif dan efisien dengan tetap memperhatikan prinsip perpajakan. Prinsip perpajakan yang dimaksud menurut Adam Smith (n.d., dikutip dalam Kuncoro, 2015) yakni keadilan (equality) yang setara bagi semua wajib pajak, kepastian (certainty) dengan memberikan kemudahan bagi penanggung pajak, kenyamanan (convenience) untuk melaksanakan kewajiban perpajakan, serta ekonomi (economic) untuk mencapai manfaat dari aktivitas perpajakan.

Pendapatan produktivitas PPN semakin meningkat akibat adanya kebijakan pengurangan terhadap pengecualian BKP dan/atau JKP, penghapusan tarif nol kecuali ekspor, penghapusan pengecualian pada PPN yang ditanggung pemerintah untuk barangbarang tertentu dan pajak untuk sebagian besar produk makanan kecuali makanan pokok yang dikonsumsi oleh orang miskin dan barang strategis tertentu termasuk pertanian, serta penguatan PPN melalui perluasan basis lebih lanjut, misalnya pertambangan dan hotel (Ikhsan et al., 2005).

Melihat begitu pentingnya reformasi perpajakan, Rahayu (2010) mendukung kebijakan tersebut dengan menyebutkan beberapa alasan mengapa suatu negara perlu melakukan reformasi perpajakan, antara lain:

1) Untuk menguatkan perekonomian yang tidak pasti.

2) Upaya memindahkan sektor penerimaan APBN dari migas.

3) Upaya mengikuti ketentuan global.

4) Meningkatkan pendapatan negara melalui sektor perpajakan.

Tujuan reformasi perpajakan juga dikemukakan oleh Devano \& Rahayu (2006) sebagai berikut:

1) Meningkatkan mutu pelayanan kepada wajib pajak (taxpayer's quality services).

2) Menekan terjadinya penyelundupan pajak (tax evasion) oleh wajib pajak.

3) Meningkatkan kepatuhan wajib pajak.

4) Menjalankan konsep good governance.

5) Meningkatkan dan mengoptimalkan penegakan hukum pajak, pengawasan yang ketat dalam pelaksanaan administrasi pajak yang berlaku bagi fiskus dan wajib pajak.

Gillis (1989) mengklasifikasikan dasar reformasi perpajakan dengan enam atribut:

1) Breadth of reform

2) Scope of reform

3) Revenue goals

4) Equity goals

5) Resource allocations goals

6) Timing of reform
Sistem dan peraturan perpajakan di Indonesia masih dianggap terlalu rumit, bahkan menurut Direktorat Jenderal Pajak tax ratio Indonesia pada tahun 2018 menempati posisi terendah di ASEAN dengan nominal tercatat 11\% (Suwiknyo, 2019). Terlebih lagi, Febrio Kacaribu selaku Kepala Badan Kebijakan Fiskal (Kepala BKF) mengatakan bahwa reformasi perpajakan masih perlu dilakukan akibat kondisi perekonomian Indonesia yang sedang krisis akibat Pandemi Covid-19 (Kementerian Keuangan, 2020b).

Struktur perekonomian masyarakat yang terus mengalami perubahan dan penerimaan perpajakan yang mengalami kendala di saat kebutuhan belanja meningkat untuk menangani krisis kesehatan, melindungi masyarakat rentan, dan mendukung dunia usaha menyebabkan perlunya desakan untuk menyusun langkah reformasi (Kurniati, 2021). Cahyasari (2018) menjelaskan bahwa Indonesia telah mengalami reformasi perpajakan beberapa kali sejak tahun 1983, saat ini otoritas pajak sedang memfokuskan reformasi perpajakan jilid III (2017 - 2024) yakni berupa konsolidasi, akselerasi, dan kontinuitas reformasi perpajakan sebelumnya. Reformasi perpajakan jilid III memiliki tujuan untuk melakukan perubahan pada lima pilar utama yakni Organisasi, Sumber Daya Manusia, IT dan Basis Data, Proses Bisnis, serta Peraturan Perpajakan.

Sebagai respons pemerintah untuk mendukung reformasi regulasi perpajakan, disahkannya undangundang perpajakan dalam Omnibus Law menjadi waktu yang tepat bagi Indonesia karena selaras dengan tujuan reformasi perpajakan. Omnibus Law berfokus pada upaya menjawab tantangan dan permasalahan yang penting dan mendesak, sedangkan reformasi pajak berfokus pada upaya perbaikan holistik-komprehensif pada jangka menengah hingga jangka panjang (Prastowo, 2019).

\subsection{Pajak Pertambahan Nilai}

PPN merupakan pajak yang ditetapkan atas "nilai tambah" oleh tiap industri bisnis yang dikenakan pajak. Jumlah ini sama dengan selisih antara nilai output industri (bruto penerimaan ataupun penjualan) dengan biaya masukan (barang dan jasa) yang diperoleh melalui pembelian dari orang lain yang mana dalam penghitungannya tidak mengurangi upah (McNulty, 2000). Kemudian, Joachim English mendefinisikan PPN sebagai pajak universal yang dikenakan atas kegiatan konsumsi, yang sebagian besar ialah pajak tidak langsung yang dibebankan oleh tiap individu yang terikat dengan transaksi barang kena pajak ataupun jasa kena pajak tertentu (OECD, 2011).

Sukardji (2015) membagi legal karakteristik PPN sebagai berikut:

1) PPN adalah pajak tidak langsung

Pajak tidak langsung memiliki beberapa manfaat yang dikemukakan dalam Lovely Professional University (2012), yaitu kemudahan, sulit dihindari, cakupan luas, elastis, universalitas, pengaruh pola produksi, tidak 
mempengaruhi motivasi untuk bekerja dan menabung, kesejahteraan sosial, fleksibilitas dan buoyancy.

2) PPN adalah pajak objektif

PPN sebagai pajak objektif memiliki arti bahwa baik orang pribadi maupun badan memiliki kewajiban untuk membayar pajak yang ditentukan dari adanya konsumsi objek kena pajak sehingga tidak memperhatikan kondisi subjektif subjek pajak karena tidak memiliki korelasi dalam pengenaan PPN.

3) PPN bersifat multi stage levy

Multi stage levy memiliki pengertian bahwa PPN dikenakan berulang kali pada setiap tahap dalam rantai jalur produksi dan tahap distribusi BKP ataupun JKP.

4) Penghitungan PPN menggunakan indirect substraction method

Indirect substraction method juga biasa disebut credit method yang mana dalam penerapannya di Indonesia berlaku Pajak Keluaran yang dikurangi dengan Pajak Masukan, dalam pengenaan PPN PKP dapat mengkreditkan Pajak Masukan atas pembelian barang atau perolehan jasa. Pada dasarnya Pajak Masukan dan Pajak Keluaran dinilai secara terpisah, pengkreditan Pajak Masukan dapat diklaim menggunakan Faktur Pajak pembelian (Le, 2003).

5) PPN bersifat non kumulatif

Karakteristik PPN yang multi stage levy dan non kumulatif menyebabkan tidak adanya cascading effect atau pengenaan pajak berganda.

6) PPN Indonesia menganut tarif tunggal (single rate)

Tarif tunggal PPN yang berlaku di Indonesia adalah $10 \%$ dan dapat dinaikkan maksimal sebesar $15 \%$ dan diturunkan maksimal sebesar 5\%. Pengenaan tarif tunggal tidak mempertimbangkan PPN atas ekspor yang menerapkan tarif $0 \%$ atas ekspor BKP, ekspor BKPTB, dan ekspor JKP.

Antic (2014, dikutip dalam Darussalam et al., 2018) menyatakan penggunaan tarif tunggal dinilai dapat membentuk kepatuhan yang signifikan terhadap administrasi pajak, mengurangi penyimpangan di pasar internal, dan meningkatkan kesejahteraan konsumen. 7) PPN merupakan pajak atas konsumsi dalam negeri

Pajak konsumsi dalam negeri mencerminkan prinsip PPN yakni destination principle yang memiliki arti bahwa lingkup teritorial PPN hanya dikenakan atas dan untuk tujuan konsumsi barang dan/atau jasa yang terjadi di dalam yurisdiksi tempat konsumsi berlangsung tanpa memandang dari mana perolehan barang atau jasa tersebut berasal.

Pohan (2016) menjelaskan apabila pajak konsumsi hanya dikenakan atas pendapatan yang dikonsumsi saja, akan meminimalisir adanya penghalang bagi masyarakat untuk menabung dan meningkatkan modal untuk diinvestasikan yang nantinya akan berdampak positif ke penghasilan ekonomi yang lebih solid dan kuat. Selain itu, terbukti di beberapa negara Eropa yang menggunakan PPN sebagai pengaplikasian pajak konsumsi dapat menumbuhkan pendapatan negara tanpa menimbulkan economic damage jangka panjang terhadap perekonomian negara (Pohan, 2016).

8) PPN yang diterapkan di Indonesia adalah Consumption Type Vat

PPN sebagai pajak atas konsumsi memberikan perbedaan yang signifikan dengan Pajak Penghasilan karena PPN bukan merupakan pajak atas kegiatan bisnis (Sukardji, 2015). Dengan demikian, pengenaan PPN hanya dibebankan atas konsumsi pribadi saja.

Pajak Pertambahan Nilai juga memiliki sifat netral. Terkait netralitas PPN, pada dasarnya PPN tidak boleh mengganggu persaingan antara bisnis asing dan domestik, atau dengan kata lain PPN tidak boleh menghalangi bisnis untuk berinvestasi atau melakukan aktivitas di negara tertentu. Sistem PPN dipersiapkan untuk diterapkan secara adil dan merata, jelas dan konsisten, serta memastikan tidak terdapat keunggulan kompetitif yang tidak adil yang diberikan kepada domestik ataupun bisnis asing yang dapat mendistorsi perdagangan internasional dan membatasi pilihan konsumen (OECD, 2017).

\subsection{Pengusaha Kena Pajak}

Pajak Pertambahan Nilai berdasarkan legal karakteristiknya merupakan pajak objektif, dalam artian bahwa pengenaan pajak pertama kali memperhatikan objeknya kemudian melihat subjeknya (Pohan, 2016). Dengan demikian, apabila objek yang dimaksud termasuk objek yang dikenakan pajak, subjek pajak dalam hal ini orang pribadi atau badan harus memungut PPN kepada pembeli. Williams (1996, dikutip dalam Darussalam et al., 2018) menyatakan hak diberikannya pengukuhan PKP secara sukarela bagi pengusaha kecil dinilai sangat tepat.

\subsection{Ruang Lingkup Pengkreditan Pajak Masukan}

Menurut Rogers \& Glabush (2015) Pajak Masukan merupakan bagian dari Pajak Pertambahan Nilai yang harus dibayarkan oleh pengusaha atas perolehan barang dan jasa untuk tujuan bisnis. Ebrill et al. (2001, dikutip dalam Pohan, 2016) menjelaskan mengenai fitur utama PPN salah satunya adalah pemungutan pajak yang dilakukan oleh pelaku bisnis. Ketika penjual mengenakan pajak kepada pembeli atas penjualan mereka, dalam hal ini pajak keluaran, maka pelaku bisnis juga berhak mengklaim pengkreditan Pajak Masukan yang telah dikenakan kepada pembeli mereka.

Definisi nilai tambah menurut Tait (1988) dilihat dari sisi aditif yakni adanya penambahan nilai antara upah dan keuntungan serta sisi substraktif yaitu pengurangan antara input dan output, dari rumus tersebut dapat disimpulkan terdapat keterkaitan antara nilai tambah PPN dengan pengkreditan Pajak Masukan.

(ECJ) European Court of Justice menyatakan bahwa hak untuk melakukan pengkreditan Pajak Masukan merupakan bagian integral PPN, latar belakang yang mendasari adanya hak pengkreditan Pajak Masukan adalah untuk mencapai prinsip 
netralitas atas seluruh kegiatan ekonomi (Darussalam et al., 2018).

\subsection{SPT Masa PPN 1111 DM}

Kementerian Koperasi dan Usaha Kecil Menengah menyatakan bahwa tidak sedikit pelaku UMKM yang segan berhubungan dengan pihak DJP, hal tersebut disebabkan mayoritas pelaku UMKM dianggap belum sepenuhnya paham mengenai perpajakan (CNN Indonesia, 2020).

Wijaya \& Chandika (2020) menggambarkan format SPT Masa PPN 1111 DM yang disesuaikan dengan UU PPN 1984. Dalam format tersebut digambarkan SPT Masa PPN 1111 DM memiliki format yang serupa dengan SPT Masa PPN 1111 pada kolom Penyerahan Barang dan Jasa, kolom penghitungan PPN kurang bayar/lebih bayar hampir sama namun terdapat penekanan pada kalimat Penyerahan Barang dan Penyerahan Jasa pada kolom Pajak Keluaran dan Pajak Masukan diganti dengan Penyerahan Barang Kena Pajak dan Penyerahan Jasa Kena Pajak untuk memastikan bahwa komponen Pajak Masukan dan Pajak Keluaran yang dapat diperhitungkan hanya atas barang dan/atau jasa yang dikenakan pajak.

\section{HASIL DAN PEMBAHASAN}

\subsection{Pengkreditan Pajak Masukan Menggunakan Pedoman Penghitungan Pengkreditan Pajak Masukan Sebelum Pengusaha Dikukuhkan Sebagai PKP}

Perubahan UU PPN tahun 2009 terdapat di Pasal 112 UU Cipta Kerja, Relaksasi Pengkreditan Pajak Masukan diatur lebih lanjut pada Pasal 9 UU PPN yang ada di UU Cipta Kerja tersebut. Hak mengkreditkan Pajak Masukan yang diberikan oleh DJP bagi PKP terdiri dari empat kemudahan yaitu pengkreditan Pajak Masukan sebelum PKP dengan tarif $80 \%$, pengkreditan sebelum melakukan penyerahan, pengkreditan saat dilakukan pemeriksaan, serta pengkreditan yang ditagih dengan ketetapan pajak. Secara keseluruhan tujuan adanya Relaksasi Pengkreditan Pajak Masukan menurut beberapa narasumber adalah untuk memberikan keadilan dan meningkatkan kepatuhan wajib pajak.

Bapak Ilham memberikan ilustrasi terkait permasalahan pengkreditan Pajak Masukan yang dilakukan pengusaha sebelum dikukuhkan menjadi PKP sebelum adanya Relaksasi Pengkreditan Pajak Masukan.

Ketika kasusnya itu penyerahan dilakukan untuk sebelum jadi PKP, otomatis kan DJP ngambil 10\% langsung nih dari total penyerahan dia tanpa ada dikurangi PM-nya, jadi PM-nya nol, otomatis pengusaha akan dibebani pajak sebesar 10\% tuh. Langsung 10\% dikurangi nol karena PM-nya nol. Nah itu kan karena margin dari pengusaha itu sendiri sebetulnya ga sampe tuh 10\% jadi banyak yang gagal bayar, kalo gagal bayar kan otomatis akan mematikan banyak pengusaha kalo memang kasusnya seperti itu (Bapak Ilham, Pelaksana Direktorat Peraturan Perpajakan I).

Pelaku usaha rata-rata memiliki margin atau keuntungan antara $2 \%$ hingga $5 \%$, ketika DJP memaksa pengusaha yang belum dikukuhkan sebagai PKP kemudian dikukuhkan sebagai PKP secara jabatan, PKP tersebut harus membayar pajak sebesar $10 \%$ dari penyerahan, padahal keuntungan yang diperoleh PKP tersebut kurang dari $10 \%$ sehingga dianggap memberatkan. Hal tersebut yang menyebabkan kurang adanya keadilan otoritas pajak terhadap PKP (Ilham, 2021).

Tn ABC menjelaskan, bagi PKP yang dikukuhkan secara jabatan karena ditemukan data ketidakpatuhan wajib pajak yang seharusnya wajib menjadi PKP tetapi belum dikukuhkan sebagai PKP, memiliki hak untuk mengkreditkan Pajak Masukan atas perolehan BKP atau JKP yang dikenakan PPN saat pengusaha tersebut belum dikukuhkan menjadi PKP. Hak tersebut diberikan dengan adanya win-win solution antara wajib pajak dengan DJP melalui Relaksasi Pengkreditan Pajak Masukan, yaitu pengaturan mengenai diperbolehkannya pengkreditan Pajak Masukan bagi PKP sebelum pengusaha dikukuhkan sebagai PKP dengan Pajak Masukan sebesar 80\% dari Pajak Keluaran. Kebijakan ini memberikan keadilan bagi kedua belah pihak baik itu DJP maupun wajib pajak. Otoritas pajak tetap memperoleh penerimaan pajak dan PKP dapat mengkreditkan Pajak Masukan dengan batasan tarif $80 \%$.

Di dalam Pasal 9 ayat (9a) perubahan UU PPN di UU Cipta Kerja menyatakan sebagai berikut:

Pajak Masukan atas perolehan Barang Kena Pajak dan/atau Jasa Kena Pajak, impor Barang Kena Pajak serta pemanfaatan Barang Kena Pajak Tidak Berwujud dan/atau pemanfaatan Jasa Kena Pajak dari luar Daerah Pabean di dalam Daerah Pabean sebelum Pengusaha dikukuhkan sebagai Pengusaha Kena Pajak, dapat dikreditkan oleh Pengusaha Kena Pajak dengan menggunakan pedoman pengkreditan Pajak Masukan sebesar $80 \%$ (delapan puluh persen) dari Pajak Keluaran yang seharusnya dipungut.

Perlu dicermati bahwa kalimat di atas memiliki 2 kontradiksi yaitu 'sebelum pengusaha dikukuhkan sebagai PKP' dan 'PKP dapat mengkreditkan Pajak Masukan'.

Ketentuan dalam Pasal 9 ayat (9a) mengindikasikan bahwa pengusaha yang belum menjadi PKP diperkenankan mengkreditkan Pajak Masukan tanpa dikukuhkan sebagai PKP dahulu, tetapi pada kalimat selanjutnya menyatakan bahwa PKP-lah yang dapat mengkreditkan Pajak Masukan. Hal tersebut menyebabkan adanya salah kaprah terhadap wajib pajak. Kembali lagi ke prinsip PPN bahwa hanya PKP yang dapat mengkreditkan Pajak Masukan, jika benar UU Cipta Kerja mengubah syarat pengkreditan Pajak Masukan maka Relaksasi Pengkreditan Pajak Masukan sebelum pengusaha dikukuhkan sebagai PKP tidak sesuai dengan prinsip dan karakteristik PPN.

Tabel 1 - Ketentuan Pengusaha yang Dapat Mengkreditkan Pajak Masukan

Narasumber 


\begin{tabular}{|c|c|}
\hline $\begin{array}{l}\text { Ilham } \\
\text { (Pelaksana } \\
\text { Direktorat } \\
\text { Peraturan } \\
\text { Perpajakan I) }\end{array}$ & $\begin{array}{l}\text { Harus dikukuhkan sebagai } \\
\text { PKP terlebih dahulu baik } \\
\text { secara jabatan maupun } \\
\text { self assessment. }\end{array}$ \\
\hline $\begin{array}{l}\text { Tn ABC } \\
\text { (Akademisi, } \\
\text { Peneliti, dan } \\
\text { Praktisi } \\
\text { Perpajakan }\end{array}$ & $\begin{array}{lr}\text { Non-PKP } & \text { boleh } \\
\text { mengkreditkan } & \text { Pajak } \\
\text { Masukan in case terjadi } \\
\text { pengukuhan PKP secara } \\
\text { jabatan. }\end{array}$ \\
\hline $\begin{array}{l}\text { Rachmad } \\
\text { (Dosen } \\
\text { Politeknik } \\
\text { Keuangan } \\
\text { Negara STAN) }\end{array}$ & $\begin{array}{l}\text { Menurut kajian teoritis } \\
\text { pengusaha harus } \\
\text { teradministrasi dahulu di } \\
\text { otoritas pajak sebagai } \\
\text { taxable person/PKP. }\end{array}$ \\
\hline
\end{tabular}

Sumber: Diolah dari hasil wawancara

Ketiga narasumber setuju bahwa seharusnya pihak yang dapat mengkreditkan Pajak Masukan adalah PKP, sesuai dengan prinsip PPN dan pendapat para ahli. PKP sebagai taxable person tentunya harus teradministrasi dahulu di dalam data yang dimiliki Direktorat Jenderal Pajak sehingga dokumen yang menjadi acuan dalam pengkreditan Pajak Masukan yakni Faktur Pajak dapat terkoneksi dan dapat dengan mudah diawasi oleh pemerintah (Rachmad, 2021).

Bapak Rachmad menjelaskan bahwa mustahil dapat dilakukan pengkreditan Pajak Masukan ketika pengusaha belum tercatat menjadi PKP karena tidak ada mekanisme pengawasan dari DJP untuk memantau pengkreditan Pajak Masukan tersebut. Sejatinya, pengkreditan Pajak Masukan pada Pasal 9 ayat (9a) memiliki arti bahwa pengusaha yang belum menjadi PKP dapat mengkreditkan Pajak Masukan sebesar 80\% dengan syarat pengusaha tersebut sudah memenuhi ketentuan menjadi PKP sehingga dapat dikukuhkan sebagai PKP terlebih dahulu sebelum mengkreditkan Pajak Masukan. Bapak Ilham mengatakan bahwa DJP membuka dua jalur bagi pengusaha yang mau menggunakan hak Relaksasi Pengkreditan Pajak Masukan untuk dikukuhkan sebagai PKP, yakni secara jabatan (official assessment) dan secara sukarela (self assessment).

Pengukuhan PKP secara jabatan wajib dilakukan ketika peredaran usaha pengusaha terkait melebihi 4,8 miliar, namun karena kelalaian wajib pajak baik itu secara sengaja maupun tidak sengaja maka wajib dilakukan pengukuhan sebagai PKP secara jabatan. Apabila PKP dikukuhkan secara jabatan, penghitungan Pengkreditan Pajak Masukan dilakukan oleh pihak DJP untuk penghitungan Pajak Keluaran dan Pajak Masukannya.

Selanjutnya, PKP yang dikukuhkan secara jabatan ditarik mundur penghitungan pajaknya maksimal lima tahun. Misalkan pengusaha memiliki peredaran usaha melebihi 4,8 miliar di tahun 2014, kemudian dikukuhkan secara jabatan sebagai PKP tahun 2020, maka dalam kasus ini DJP hanya dapat menghitung pajak terutang atas transaksi-transaksi sejak tahun 2015 sampai 2020.
Kebijakan pengkreditan Pajak Masukan bagi pengusaha yang belum menjadi PKP dapat dipastikan selalu menghasilkan PPN kurang bayar untuk periode sebelum pengusaha tersebut menjadi PKP karena dihitung menggunakan Pedoman Pengkreditan Pajak Masukan sebesar $80 \%$ dari Pajak Keluaran. Kecil kemungkinan terjadi SPT nihil atau lebih bayar karena jumlah Pajak Keluaran sebagai pengurang lebih besar daripada nominal Pajak Masukan sehingga negara tetap menerima sebesar $2 \%$ dari pajak terutang.

Berdasarkan data dari Direktorat Data dan Informasi Perpajakan, jumlah PKP yang telah menggunakan pengkreditan Pajak Masukan dengan tarif $80 \%$ pada bulan November 2020 sejumlah 729 orang dan pada bulan Desember 2020 sejumlah 641 orang. Disusul pada tahun 2021 bulan Januari terdapat penambahan wajib pajak sebesar 661 orang dan bulan Februari sejumlah 616 orang. Dari data tersebut dapat disimpulkan dengan adanya penambahan wajib pajak yang menggunakan hak Relaksasi Pengkreditan Pajak Masukan otomatis menambah jumlah PKP terdaftar.

Sementara itu, Bapak Rachmad menyatakan bahwa secara teoritis pengusaha yang dapat mengkreditkan Pajak Masukan kurang tepat dan belum terlalu memahami bagaimana penerapan pengkreditan Pajak Masukan sebelum dikukuhkan sebagai PKP.

Pasalnya, pengkreditan Pajak Masukan sebesar 80\% memang ditujukan dan hanya dapat digunakan oleh pengusaha yang belum dikukuhkan sebagai PKP yang kemudian menjadi PKP setelah disahkannya peraturan tersebut. Hal tersebut dikarenakan penghitungan Pajak Masukan dan Pajak Keluaran mulai dihitung sejak masa pajak sebelum pengusaha menjadi PKP, sehingga pengusaha yang sudah menjadi PKP sebelum disahkannya Relaksasi Pengkreditan Pajak Masukan tidak dapat menggunakan metode pengkreditan Pajak Masukan tersebut.

Besaran tarif $80 \%$ didapatkan dari kajian yang dilakukan pihak otoritas pajak yang terinspirasi dari PMK Nomor 79/PMK.03/2010 terkait PKP yang melakukan kegiatan usaha tertentu, yaitu penyerahan emas perhiasan secara eceran yang mana atas penyerahan tersebut sudah tidak berlaku lagi. Pengkreditan Pajak Masukan sebesar $80 \%$ oleh pengusaha sebelum PKP sama dengan pengkreditan Pajak Masukan atas penyerahan emas perhiasan secara eceran. Pihak DJP mengambil angka persentase tersebut karena dirasa angka $90 \%$ yang merupakan tarif atas penyerahan kendaraan bermotor bekas terlalu besar sehingga dapat menimbulkan kerugian bagi otoritas pajak karena DJP hanya memperoleh pajak sebesar $1 \%$ saja. Selain itu, persentase $80 \%$ dipilih karena apabila dilihat secara agregat, rata-rata keuntungan pengusaha net-income nya hanya sekitar $2 \%$ sampai $3 \%$. (Ilham, 2021).

Tn ABC berpendapat bahwa persentase $80 \%$ terlampau besar untuk deemed Pajak Masukan sebelum pengusaha menjadi PKP karena untuk Pedoman 
Pengkreditan Pajak Masukan masih berpatokan pada PMK 74/PMK.03/2010 yang saat ini masih berlaku. Bapak Rachmad berpendapat tarif $80 \%$ mungkin didapatkan dari kompromi antara eksekutif dan legislatif yang dianggap wajar saat itu. Hal ini dijelaskan lebih lanjut oleh Bapak Ilham bahwa pihak DJP dalam menentukan tarif tentunya berpedoman dari data-data dan kajian yang telah dilakukan serta pertimbangan dari para pemimpin. Fokus utama DJP adalah meningkatkan penerimaan pajak dengan tetap berlandaskan keadilan bagi kedua belah pihak salah satunya dengan mempertimbangkan rata-rata margin para pelaku usaha. Selain itu, meskipun ada pengusaha yang memiliki keuntungan lebih dari rata-rata margin PKP, DJP tetap mendapatkan keuntungan $2 \%$ dari PPN terutang.

\subsection{Konflik antara PMK 74 Tahun 2010 dengan Peraturan Perundang-Undangan Lainnya}

4.2.1 Perbedaan Tarif Pedoman Penghitungan Pengkreditan Pajak Masukan

Pengusaha yang telah menjadi PKP sebelum berlakunya Relaksasi Pengkreditan Pajak Masukan tidak diperkenankan menggunakan Pedoman Penghitungan Pengkreditan Pajak Masukan sebesar 80\%, hal ini menimbulkan kontroversi terkait PKP yang memenuhi kriteria pengusaha dalam PMK 74/PMK.03/2010. Kebijakan ini tampaknya menimbulkan pertentangan karena Direktorat Jenderal Pajak kurang memberikan keadilan bagi PKP yang sebelumnya telah memilih menggunakan Pedoman Penghitungan Pengkreditan Pajak Masukan sesuai ketentuan di dalam PMK 74/PMK.03/2010.

Tn ABC dan Bapak Ilham mengatakan bahwa pada tahun 2010 terbit peraturan baru yakni PMK 74/PMK.03/2010 yang tujuan awalnya adalah simplifikasi atau untuk memberikan kemudahan bagi PKP baru yang memiliki peredaran usaha kurang dari 1,8 miliar.

Untuk menjadi PKP tentunya memiliki kewajiban yang lebih berat dari non-PKP seperti membuat Faktur Pajak, mengkreditkan Pajak Masukan, hingga mengisi dan melaporkan SPT. Pada dasarnya peraturan ini bersifat opsional, simplifikasi PMK 74/PMK.03/2010 ditujukan untuk merangsang PKP baru yang omzetnya tidak terlalu besar dengan melatih PKP menggunakan ketentuan Pedoman Penghitungan Pengkreditan Pajak Masukan yang notabenenya lebih mudah daripada Mekanisme Umum Pengkreditan Pajak Masukan.

Tn ABC menggambarkan konflik antara PKP patuh dengan PKP tidak patuh. Dalam kasus ini terdapat PKP patuh, yaitu pengusaha yang memiliki peredaran usaha tidak lebih dari 1,8 miliar dan telah dikukuhkan menjadi PKP sejak lama. PKP tersebut dalam melaksanakan kewajiban sebagai PKP mengacu pada ketentuan PMK 74 tahun 2010 yaitu dapat mengkreditkan Pajak Masukan sebesar $60 \%$ atau $70 \%$ atas penyerahan barang atau jasa. Di sisi lain terdapat PKP tidak patuh, yaitu PKP yang memiliki peredaran usaha dalam satu tahun melebihi 4,8 miliar tetapi baik sengaja maupun tidak sengaja PKP tersebut tidak melaksanakan kewajiban sebagai PKP tepat waktu sehingga harus dilakukan pengukuhan PKP jabatan oleh DJP atau secara sukarela mengukuhkan diri sebagai PKP setelah berlakunya UU Cipta Kerja.

Peraturan Menteri Keuangan 74/PMK.03/2010 mengatur bahwa PKP yang menggunakan Pedoman Pengkreditan pajak Masukan dapat mengkreditkan Pajak Masukan sebesar 60\% untuk JKP dan 70\% untuk BKP. Sedangkan di UU Cipta Kerja, terdapat tarif baru untuk mengkreditkan Pajak Masukan dengan menggunakan Pedoman Pengkreditan Pajak Masukan sebesar $80 \%$ bagi pengusaha yang belum dikukuhkan sebagai PKP. Hal inilah yang menimbulkan persengketaan antara PKP patuh dan PKP tidak patuh karena PKP patuh hanya dapat mengkreditkan Pajak Masukan dengan persentase yang lebih kecil daripada PKP tidak patuh.

Dari sisi kepatuhan seharusnya pengusaha yang sudah menjadi PKP sejak lama mempunyai hak untuk memperoleh keuntungan yang lebih besar terkait pembayaran pajak yaitu dengan pemberian tarif Pengkreditan Pajak Masukan yang lebih besar. Singkatnya, PKP patuh perlu membayar PPN terutang sebesar 3\% untuk penyerahan Barang Kena Pajak dan $4 \%$ untuk Jasa Kena Pajak ke kas negara sedangkan PKP tidak patuh hanya $2 \%$ saja baik atas penyerahan Barang Kena Pajak maupun Jasa Kena Pajak, sehingga terlihat kurang adil bagi PKP yang sudah terlanjur memilih PMK 74/PMK.03/2010 sebagai pedoman dasar untuk mengkreditkan Pajak Masukan.

Kebijakan Relaksasi Pengkreditan Pajak Masukan UU Cipta Kerja selain menimbulkan respons positif bagi pengusaha yang belum dikukuhkan sebagai PKP juga memberikan respons negatif bagi pengusaha pengguna Pedoman Penghitungan Pengkreditan Pajak Masukan yang sudah dikukuhkan sebagai PKP.

Tabel 2 - Hubungan antara PMK 74/PMK.03/2010 dengan Relaksasi Pengkreditan Pajak Masukan

\begin{tabular}{|l|l|}
\hline \multicolumn{1}{|c|}{ Narasumber } & \multicolumn{2}{|c|}{ Pendapat } \\
\hline $\begin{array}{l}\text { Ilham (Pelaksana } \\
\text { Direktorat }\end{array}$ & $\begin{array}{l}\text { PMK } 74 \text { tahun 2010 } \\
\text { sebenarnya memang sudah } \\
\text { Perpajakan I) } \\
\text { tidak relevan dalam kondisi } \\
\text { saat ini karena sudah berlaku } \\
\text { UU Cipta Kerja dengan tarif } \\
\text { pengkreditan Pajak Masukan }\end{array}$ \\
$\begin{array}{l}\text { Tn ABC (Akademisi, } \\
\text { Peneliti, dan Praktisi } \\
\text { Perpajakan }\end{array}$ & $\begin{array}{l}\text { Kurang adil bagi PKP yang } \\
\text { menggunakan PMK 74 tahun } \\
2010, \text { setidaknya tarif dalam } \\
\text { PMK 74 disamakan dengan } \\
\text { UU Cipta Kerja yaitu 80\%. }\end{array}$ \\
\hline $\begin{array}{l}\text { Rachmad } \\
\text { Politeknik } \\
\text { Keuangan Negara } \\
\text { STAN) }\end{array}$ & $\begin{array}{l}\text { Belum tahu pasti bagaimana } \\
\text { penerapan tarif 80\% untuk } \\
\text { pengkreditan Pajak Masukan. }\end{array}$ \\
\hline
\end{tabular}

Sumber: Diolah dari hasil wawancara 
Menurut Bapak Ilham, pengesahan UU Cipta Kerja dan berlakunya Relaksasi Pengkreditan Pajak Masukan mengakibatkan tidak relevannya ketentuan di dalam PMK 74/PMK.03/2010. Tetapi hingga saat ini, PMK 74/PMK.03/ 2010 belum dicabut dan masih banyak PKP yang menggunakan Pedoman Pengkreditan Pajak Masukan sesuai ketentuan peraturan menteri keuangan tersebut. Perbedaan tarif Pajak Masukan yang diberikan PKP patuh dan PKP tidak patuh memiliki gap, setidaknya PMK 74/PMK.03/2010 dilakukan revisi terkait besaran persentase pengkreditan Pajak Masukan untuk disamakan dengan persentase Pengkreditan Pajak Masukan di dalam UU Cipta Kerja yaitu $80 \%$ dalam rangka memberikan keadilan bagi sesama Pengusaha Kena Pajak (ABC, 2021).

4.2.2 Definisi Peredaran Usaha bagi Pengusaha Kena Pajak

Setiap PKP memiliki peredaran usaha yang berasal dari kegiatan usaha, dijelaskan pada Surat Edaran Direktur Jenderal Pajak Nomor SE - 02/PJ/2015 mengenai penjelasan Pasal 31E Undang-Undang Nomor 36 Tahun 2008 tentang Pajak Penghasilan, peredaran usaha yang lebih dikenal sebagai peredaran bruto merupakan seluruh penghasilan bruto yang diperoleh baik dari kegiatan usaha maupun dari luar kegiatan usaha sebelum dikurangi biaya-biaya untuk $3 \mathrm{M}$, yaitu mendapatkan, menagih, dan memelihara penghasilan. Peredaran bruto tersebut meliputi seluruh penghasilan baik itu penghasilan yang terutang pajak maupun tidak terutang pajak karena dalam penjelasan tersebut mencantumkan unsur penghasilan final, non final, dan dikecualikan dari objek pajak.

Lebih lanjut, di dalam PMK 74/PMK.03/2010 tertuang batasan peredaran usaha yang menjadi acuan PKP untuk mengkreditkan Pajak Masukan, namun tidak dijelaskan secara detail apa definisi dari peredaran usaha tersebut. Apabila mengikuti ketentuan definisi peredaran usaha dalam UU PPh maka dalam penghitungan peredaran usaha untuk mencari PPN terutang mencantumkan seluruh penyerahan barang dan jasa baik itu BKP, JKP, BKPTB, non-BKP, non-JKP, hingga objek yang mendapat fasilitas dibebaskan dan tidak dipungut PPN.

Tidak hanya undang-undang PPh, dalam lampiran PER-10/PJ/2013 mengenai tata cara pengisian SPT Masa PPN 1111 DM menjelaskan bahwa pada bagian isi kolom Penyerahan Barang dan Jasa meliputi seluruh penyerahan barang dan jasa. Pernyataan tersebut dianggap bias karena mengandung arti bahwa dalam menghitung batasan peredaran usaha harus mencantumkan seluruh komponen barang dan jasa, padahal prinsip penghitungan Pajak Masukan dan Pajak keluaran hanya atas penyerahan barang dan/atau jasa yang dikenakan pajak saja. Apabila atas Pajak Masukan dan Pajak Keluaran terkandung barang atau jasa yang seharusnya tidak terutang PPN akan menyebabkan kesalahan penghitungan.
Bapak Rachmad mengatakan bahwa peredaran usaha dalam PPN hanya berlaku untuk BKP dan JKP saja, ketika terdapat penyerahan yang seharusnya tidak terutang PPN dan kemudian penghasilan tersebut masuk ke total peredaran usaha harus dikeluarkan terlebih dahulu secara proporsional, hal tersebut juga didukung oleh pernyataan Bapak Ilham yang mengatakan bahwa meskipun saat ini PMK 74/PMK.03/2010 masih berlaku, terkait definisi peredaran usaha bagi PKP saat ini mengacu pada PMK 179/PMK.03/2013 yang mana frasa peredaran usaha sudah dihilangkan dan diganti dengan peredaran bruto. Peredaran bruto yang dimaksud hanya atas penyerahan BKP dan JKP saja yang diperhitungkan ke dalam threshold PPN. Sesuai dengan filosofi PPN, apabila ada penyerahan non BKP atau non JKP maka tidak terdapat isu PPN di dalamnya sehingga harus dikeluarkan terlebih dahulu.

Apabila PKP dalam suatu masa pajak melakukan penyerahan yang terutang pajak dan tidak terutang pajak maka perlu melakukan pemisahan antara penghasilan dari penyerahan yang terutang pajak dan tidak terutang pajak. Misalkan Pengusaha Kena Pajak melakukan penyerahan susu segar yang belum diolah dan susu yang sudah dikemas ke supermarket, atas penyerahan susu segar tidak terutang PPN karena merupakan barang yang dikecualikan dari pengenaan PPN sehingga PKP hanya perlu mencantumkan peredaran bruto atas penyerahan susu kemasan. Namun apabila PKP tidak mengetahui dengan pasti penyerahan mana saja yang terutang dan tidak terutang pajak, maka dilakukan penghitungan kembali Pajak Masukan sesuai ketentuan pada Pasal 9 ayat (6) UU PPN.

Bapak Rachmad memberikan ilustrasi mengenai peredaran usaha yang mengakibatkan pengusaha diwajibkan menjadi PKP. "Misalkan dia menjual beras 10 miliar ya tidak menjadi PKP, tapi kalau dia menjual 10 miliar beras dan 5 miliar tepung beras ya dia PKP". Mengenai definisi peredaran usaha bagi PKP memang masih perlu dilakukan sosialisasi yang masif karena untuk melakukan penghitungan secara proporsional guna memisahkan penyerahan yang kena pajak dan tidak kena pajak masih dilakukan penghitungan secara manual dan harus dilakukan penyesuaian kembali di 3 bulan setelah berakhirnya tahun pajak. Selain itu, perlu adanya peraturan turunan yang menjelaskan definisi dari peredaran usaha atau peredaran bruto secara eksplisit sehingga kejelasan ketentuan di dalam suatu peraturan dapat diterima dengan baik oleh masyarakat. 1.3.3.1 Adanya Ruang Kosong Mengenai Batasan Peredaran Usaha PKP

Setiap negara memiliki variasi tersendiri terkait batasan peredaran usaha dan tidak menetapkan standar ambang batas 'satu ukuran untuk semua' karena negara yang berbeda berada dalam tahap perkembangan yang berbeda pula, mulai dari segi 
struktur ekonomi hingga administrasi pajak setiap negara memiliki kapasitas yang berbeda (Le, 2003).

Sebelum adanya Peraturan Menteri Keuangan 74/PMK.03/2010, peraturan yang terakhir kali diubah mengenai ketentuan batasan peredaran usaha bagi pengusaha yang dikukuhkan menjadi PKP mengacu pada Peraturan Menteri Keuangan 68/PMK.03/2010 yaitu harus memiliki peredaran bruto lebih dari Rp600.000.000,00. Pada tahun yang sama terbit PMK 74/PMK.03/2010 yang bertujuan untuk memudahkan PKP baru, PKP yang memenuhi syarat untuk menggunakan Pedoman Pengkreditan Pajak Masukan harus memiliki peredaran usaha tidak lebih dari Rp1.800.000.000,00 (Ilham, 2021).

Pada saat itu, terdapat dua pilihan bagi pengusaha yang wajib dikukuhkan sebagai PKP, apabila PKP ingin menggunakan Mekanisme Umum Pengkreditan Pajak Masukan mengikuti ketentuan PMK 68/PMK.03/2010 sedangkan opsi lain yang penghitungannya lebih mudah yaitu menggunakan Pedoman Pengkreditan Pajak Masukan PKP dapat menggunakan ketentuan PMK 74/PMK.03/2010.

Le (2003) menyatakan bahwa ambang batas yang rendah menghasilkan masalah kepatuhan dan administrasi yang pada akhirnya mengancam keberlangsungan sistem PPN secara keseluruhan. Praktik di lapangan menggambarkan bahwa banyak negara memulai PPN dengan ambang rendah, tetapi setelah beberapa periode pemerintah menyadari kebutuhan untuk menyesuaikan batas peredaran usaha ke tingkat yang lebih tinggi secara signifikan.

Batasan peredaran usaha memang merupakan aspek penting yang harus diperhatikan dalam pengimplementasian pengukuhan PKP. Mengenai hal tersebut pada tahun 2013 terbit PMK 197/PMK.03/2013 yang merupakan perubahan dari PMK 68/PMK.03/2010, dalam peraturan tersebut threshold PPN atau batasan peredaran bruto diubah menjadi 4,8 miliar. Dengan demikian hingga saat ini ketentuan pengusaha yang wajib menjadi PKP harus memiliki peredaran bruto lebih dari 4,8 miliar dan wajib menggunakan Mekanisme Umum Pengkreditan Pajak Masukan dengan tarif Pajak Masukan dan Pajak Keluaran masing-masing sebesar $10 \%$.

Tabel 3 Batasan Peredaran Usaha bagi PKP di dalam PMK 74/PMK.03/2010

\begin{tabular}{|l|lr|}
\hline \multicolumn{1}{|c|}{ Narasumber } & \multicolumn{2}{|c|}{ Pendapat } \\
\hline $\begin{array}{l}\text { Ilham (Pelaksana } \\
\text { Direktorat }\end{array}$ & $\begin{array}{l}\text { Masih dilakukan kajian } \\
\text { Peraturan } \\
\text { Perpajakan I) }\end{array}$ & $\begin{array}{l}\text { lni akan kita pertahankan atau } \\
\text { dicabut karena PMK 74 sudah } \\
\text { tidak relevan lagi. }\end{array}$ \\
\hline $\begin{array}{l}\text { Tn ABC (Akademisi, } \\
\text { Peneliti, dan } \\
\text { Praktisi Perpajakan }\end{array}$ & $\begin{array}{l}\text { Sebaiknya batasan peredaran } \\
\text { usaha 1,8 M direvisi } \\
\text { disamakan saja dengan 4,8 M } \\
\text { agar adil. }\end{array}$ \\
\hline $\begin{array}{l}\text { Rachmad } \\
\text { Politeknik }\end{array}$ & $\begin{array}{l}\text { Agar ideal angka } \\
\text { harusnya dicabut agar }\end{array}$ \\
\hline
\end{tabular}

$\begin{array}{lll}\begin{array}{l}\text { Keuangan Negara } \\ \text { STAN) }\end{array} & \begin{array}{l}\text { membingungkan dan } \\ \text { pengawasannya lebih mudah. }\end{array}\end{array}$

Sumber: Diolah dari hasil wawancara

Baik PMK 197/PMK.03/2013 maupun PMK 74/PMK.03/2010 keduanya masih berlaku, Tn ABC berpendapat sebaiknya PMK 74/PMK.03/2010 sebagai peraturan turunan yang lebih mudah dilakukan perubahan perlu dilakukan revisi mengenai batasan peredaran usaha bagi PKP. Angka 1,8 miliar dan 4,8 miliar memiliki ruang kosong dan dapat menimbulkan loss potential pajak sehingga perlu disamakan menjadi 4,8 miliar saja mengikuti ketentuan di UU Cipta Kerja yang merupakan peraturan terbaru. Pendapat tersebut sejalan dengan International Monetary Fund yang merekomendasikan keseragaman dalam penetapan threshold PPN untuk seluruh jenis kegiatan usaha dalam rangka kesederhanaan, efisiensi, dan transparansi Pajak Pertambahan Nilai (Ebrill et al., 2001).

Di sisi lain, Bapak Rachmad dan Bapak Ilham setuju bahwa PMK 74/PMK.03/2010 sudah tidak relevan lagi dan perlu dicabut yang artinya angka 1,8 miliar juga tidak akan berlaku lagi. Hal ini dikarenakan PMK 74/PMK.03/2010 sudah memberatkan sisi administrasi dan pengawasan pajak. Apabila dihitung secara ekonomi, perbandingan jumlah pajak yang diterima dengan Pengusaha Kena Pajak omzet tertentu, cost benefit-nya sudah tidak memiliki keterkaitan atau dengan kata lain perbandingannya sudah tidak setara (Rachmad, 2021).

Bapak Ilham mengatakan hingga saat ini pihak internal DJP masih mempertimbangkan apakah PMK 74/PMK.03/2010 akan dipertahankan, diubah, atau dicabut mengingat banyak ketentuan yang sudah tidak relevan seperti definisi peredaran usaha bagi PKP, penggunaan Pedoman Pengkreditan Pajak Masukan dengan tarif $60 \%$ dan $70 \%$, serta batasan peredaran usaha bagi PKP.

Apabila PMK 74 tahun 2010 dianggap sudah tidak relevan lagi dan seharusnya dicabut maka otoritas pajak harus siap untuk kehilangan potensi pajak dari PKP dengan omzet tertentu yang sudah menggunakan Pedoman Pengkreditan Pajak Masukan sesuai PMK 74/PMK.03/2010.

\subsection{Mekanisme Pengimplementasian Relaksasi Pengkreditan Pajak Masukan}

Bagi PKP yang menggunakan Mekanisme Umum Pengkreditan Pajak Masukan wajib mengisi dan melaporkan SPT Masa PPN 1111 untuk melaksanakan kewajibannya sebagai PKP, sedangkan PKP yang menggunakan Pedoman Penghitungan Pengkreditan Pajak Masukan sesuai PMK 74/PMK.03/2010 disandingkan dengan ketentuan PER-10/PJ/2013 yaitu mengisi SPT Masa PPN 1111 DM.

Lain halnya dengan Pedoman Pengkreditan Pajak Masukan yang digunakan PKP saat melakukan pengkreditan Pajak Masukan sebelum pengusaha dikukuhkan sebagai PKP, peraturan baru tersebut tidak memberikan kewajiban bagi PKP untuk menggunakan 
SPT baru selain SPT Masa PPN 1111 dan SPT Masa PPN 1111 DM. Mekanisme Pedoman Penghitungan Pengkreditan Pajak Masukan dengan tarif $80 \%$ tidak terdapat SPT khusus, namun tidak pula mengharuskan PKP untuk mengisi SPT Masa PPN 1111 DM mengingat penghitungan tersebut hampir serupa dengan ketentuan penghitungan pengkreditan Pajak Masukan pada PMK 74/PMK.03/2010.

Maksud dari PKP dapat mengkreditkan Pajak Masukan sebelum pengusaha dikukuhkan sebagai PKP adalah penghitungan PKP dapat mengkreditkan Pajak Masukan terhitung sejak masa pajak dalam satu tahun buku ketika pengusaha telah memiliki peredaran bruto lebih dari 4,8 miliar dan seharusnya sudah dikukuhkan menjadi PKP hingga masa pajak terakhir tepat sebelum pengusaha tersebut benar-benar dikukuhkan sebagai PKP. Misalkan PT Zac pada tahun 2020 seharusnya dikukuhkan sebagai PKP paling lambat tanggal 31 Januari 2020, namun PT Zac terlambat untuk melaporkan peredaran brutonya yang sudah melebihi 4,8 miliar dan baru dikukuhkan sebagai PKP pada tanggal 5 November 2020, oleh karena itu penghitungan penyerahan BKP atau JKP sebagai DPP untuk mencari Pajak Keluaran menggunakan Pedoman Pengkreditan Pajak Masukan dihitung sejak tanggal 31 Januari 2020 hingga 4 November 2020.

Perlu ditekankan bahwa Pedoman Pengkreditan Pajak Masukan di dalam UU Cipta Kerja hanya dapat dilakukan pengkreditan atas penyerahan sebelum dikukuhkan sebagai PKP saja, sehingga ketika PKP tersebut sudah benar-benar menjadi PKP, tarif $80 \%$ tidak dapat digunakan lagi.

Contoh :

Diketahui bahwa PT Zac sudah dikukuhkan menjadi PKP pada tanggal 5 November 2020, maka Pajak Masukan atas penyerahan BKP dan/atau JKP yang dilakukan PT Zac sejak tanggal 5 November 2020 dan seterusnya tidak dapat dikreditkan lagi menggunakan tarif $80 \%$ dari Pajak Keluaran karena sudah tidak berlaku lagi bagi PT Zac. PT Zac dikukuhkan sebagai PKP karena peredaran brutonya telah melebihi 4,8 miliar, sehingga setelah tanggal 5 November 2020 PT Zac harus menggunakan Mekanisme Umum Pajak Masukan dan Pajak Keluaran dengan tarif PPN normal untuk mengkreditkan Pajak Masukannya.

Peraturan Menteri Keuangan Nomor 18/PMK.03/2021 mengatur mengenai dua kondisi yang mana PKP tidak dapat menggunakan Pedoman Pengkreditan Pajak Masukan sebelum pengusaha dikukuhkan sebagai PKP, antara lain PKP yang menggunakan DPP nilai lain untuk menghitung pajak keluaran serta PKP yang dalam satu tahun memiliki peredaran usaha tidak melebihi jumlah tertentu dan melakukan kegiatan usaha tertentu.

Peredaran usaha dengan jumlah tertentu diatur pada PMK 74/PMK.03/2010 yaitu PKP yang memiliki peredaran bruto kurang dari 1,8 miliar. PKP dengan kegiatan usaha tertentu diatur pada PMK
79/PMK.03/2010 yaitu PKP yang melakukan penyerahan kendaraan bermotor bekas secara eceran. Kondisi di atas dikecualikan bagi PKP untuk menggunakan tarif pengkreditan $80 \%$ apabila sebelum menjadi PKP pengusaha tersebut sudah melakukan penghitungan Pedoman Pengkreditan Pajak Masukan sesuai PMK 74/PMK.03/2010 dan PMK 79/PMK.03/2010. Sebaliknya, apabila sebelum menjadi PKP belum pernah menggunakan Pedoman Pengkreditan Pajak Masukan dari dua peraturan tersebut maka PKP tetap bisa menggunakan Pedoman Pengkreditan Pajak Masukan di UU Cipta Kerja.

Pasalnya, PKP yang menggunakan PMK 74/PMK.03/2010 berdasarkan jumlah peredaran usaha tertentu adalah pengusaha yang secara sukarela dikukuhkan sebagai PKP meskipun belum memiliki kewajiban sebagai PKP. Kembali lagi ke prinsip awal bahwa kewajiban PKP adalah pengusaha yang memiliki peredaran bruto lebih dari 4,8 miliar sedangkan PKP yang menggunakan PMK tersebut peredaran brutonya belum melebihi batasan 4,8 miliar tetapi tetap diperbolehkan menjadi PKP. Berdasarkan logika di atas, PKP yang telah menggunakan PMK 74/PMK.03/2010 yang mana peredaran brutonya masih di bawah 1,8 miliar otomatis sudah dikukuhkan sebagai PKP secara self assessment, oleh karena itu PKP tersebut tidak dapat mengkreditkan Pajak Masukan sesuai UU Cipta Kerja. Di samping itu, mustahil dilakukan pengukuhan PKP dua kali meskipun peredaran bruto PKP tersebut sudah melebihi 4,8 miliar.

PKP yang menggunakan pedoman Pengkreditan Pajak Masukan dengan tarif $80 \%$ dapat menggunakan dua jenis SPT, baik itu SPT Masa PPN 1111 maupun SPT Masa PPN 1111 DM tergantung syarat yang dipenuhi PKP tersebut. Ketika PKP memiliki peredaran bruto lebih dari 4,8 miliar maka menggunakan SPT Masa PPN 1111, sedangkan PKP yang melakukan kegiatan usaha penyerahan kendaraan bermotor bekas secara eceran dan PKP yang memiliki peredaran bruto kurang dari 1,8 miliar dapat menggunakan SPT Masa PPN 1111 DM.

Bapak Ilham memberikan ilustrasi mengenai PKP dengan kegiatan usaha tertentu yang dapat menggunakan Pedoman Pengkreditan Pajak Masukan UU Cipta Kerja.

Misalnya ada pengusaha kendaraan bekas dan omzetnya sudah lebih dari 4,8 miliar tetapi belum dikukuhkan sebagai PKP, jeda antara ketika omzetnya lebih dari 4,8 M sampai dia dikukuhkan sebagai PKP Pajak Masukannya dapat dikreditkan menggunakan deemed Pajak Masukan 80\% (Bapak Ilham, Pelaksana Direktorat Peraturan Perpajakan I).

Dari ilustrasi di atas dapat dipahami bahwa PKP yang melakukan kegiatan usaha tertentu yaitu penyerahan kendaraan bermotor bekas secara eceran dan peredaran brutonya sudah melebihi 4,8 miliar wajib dikukuhkan sebagai PKP. Berdasarkan Pasal 9 ayat (7) UU PPN meskipun PKP yang melakukan kegiatan usaha tertentu memiliki peredaran bruto dalam satu tahun 
lebih dari 4,8 miliar, PKP tersebut tetap dapat menggunakan Pedoman Penghitungan Pengkreditan Pajak Masukan dan melaporkan pajak terutang menggunakan SPT Masa PPN 1111 DM.

4.3.1 Penghitungan pengkreditan Pajak Masukan pada SPT Masa PPN 1111

Berdasarkan Peraturan Menteri Keuangan 18/PMK.03/2021, Pedoman Pengkreditan Pajak Masukan sebelum pengusaha dikukuhkan sebagai PKP memiliki sedikit perbedaan dalam hal pengisian SPT mengingat format dan isi dari kedua SPT tersebut juga berbeda. Bagi pengguna SPT Masa PPN 1111 untuk melakukan deemed Pajak Masukan 80\% menggunakan formulir $1111 \mathrm{AB}$.

Pengisian Pajak Keluaran dilaporkan secara digunggung dan diisi pada kolom Rekapitulasi Penyerahan bagian I.B.2 yaitu Penyerahan Dalam Negeri dengan Faktur Pajak yang Digunggung. Sedangkan Pajak Masukan diisi pada kolom III.B.3 yaitu Hasil Penghitungan Kembali Pajak Masukan yang telah dikreditkan sebagai penambah (pengurang) Pajak Masukan, kolom ini diisi sebesar $80 \%$ dari Pajak Keluaran pada kolom I.B.2.

4.3.2 Penghitungan pengkreditan Pajak Masukan pada SPT Masa PPN 1111 DM

Bagi PKP yang menggunakan SPT Masa PPN 1111 DM bagian identitas yang perlu diberi tanda silang hanya pada kotak yang merujuk pada Berdasarkan Kegiatan Usaha, hal ini menunjukkan bahwa Pedoman Pengkreditan Pajak Masukan sebelum pengusaha dikukuhkan sebagai PKP lebih tepat digunakan PKP yang melakukan kegiatan usaha tertentu.

Sejatinya, PKP dengan batasan peredaran usaha dengan jumlah tertentu memiliki peredaran usaha di bawah 1,8 miliar, di sisi lain threshold PPN saat ini adalah 4,8 miliar dan masa pajak pengusaha sebelum dikukuhkan menjadi PKP belum mencapai 4,8 miliar sehingga tidak terdapat kewajiban PPN yang timbul untuk masa pajak tersebut. Kondisi tersebut berlaku apabila diasumsikan tidak ada fraud, namun masih ada kemungkinan bagi pengusaha dengan jumlah peredaran bruto tidak melebihi jumlah tertentu untuk menggunakan Pedoman Pengkreditan Pajak Masukan sebelum pengusaha dikukuhkan sebagai PKP (Ilham, 2021).

Pengisian Pajak Masukan dan Pajak Keluaran dalam SPT Masa PPN 1111 DM sebelum pengusaha dikukuhkan sebagai PKP sama seperti mengisi penghitungan Pedoman Pengkreditan Pajak Masukan bagi PKP yang menggunakan PMK 74/PMK.03/2010.

Pada formulir induk kolom I.A bagian penyerahan barang diisi dengan jumlah seluruh penyerahan barang kena pajak setelah dikurangi retur barang, pada kolom I.B diisi dengan jumlah seluruh penyerahan jasa kena pajak setelah dikurangi pembatalan jasa. Kemudian pada kolom II.A.1 diisi jumlah penyerahan barang kena pajak dari kolom I.A dan kolom II.A.2 diisi jumlah penyerahan jasa dari kolom
I.B, masing-masing dikalikan $10 \%$ untuk mendapatkan Pajak Keluaran. Untuk menghitung Pajak Masukan yang dapat dikreditkan mengisi kolom bagian II.C.1 untuk penyerahan barang kena pajak dan II.C.2 untuk penyerahan jasa kena pajak, masing-masing dikalikan dengan $80 \%$ dari jumlah Pajak Keluaran pada kolom II.A.1 dan II.A.2.

\subsection{Kontroversi Mengenai Format SPT Masa PPN 1111 DM}

SPT (Surat Pemberitahuan) Masa PPN merupakan surat yang digunakan oleh wajib pajak guna melaksanakan kewajibannya sebagai PKP dengan melaporkan pembayaran pajak serta mengkreditkan Pajak Masukan terhadap Pajak Keluaran. SPT ini dibagi menjadi tiga, yaitu SPT Masa PPN 1111 bagi PKP yang menggunakan penghitungan Mekanisme Umum Pengkreditan Pajak Masukan dan Pajak Keluaran, SPT Masa PPN 1111 DM bagi PKP yang menggunakan Pedoman Penghitungan Pengkreditan Pajak Masukan, dan SPT Masa PPN 1107 Put bagi pemungut PPN selain PKP contohnya bendahara pemerintah.

SPT Masa PPN 1111 dan SPT Masa PPN 1111 DM memiliki format, isi, dan tata cara pengisian yang berbeda. SPT masa PPN 1111 diatur di PER-11/PJ/2013 sebagaimana diubah dari PER-44/PJ/2010, SPT masa PPN 1111 DM diatur lebih lanjut di dalam PER10/PJ/2013 sebagai perubahan dari PER-45/PJ/2010. Terdapat sisi positif dan negatif mengenai format SPT Masa PPN 1111 DM yang dirasakan oleh beberapa pihak khususnya dari sudut pandang PKP yang pada akhirnya akan mempengaruhi penerimaan pajak pula. Selain itu, masih ditemukan pula kejanggalan mengenai tata cara pengisian SPT Masa PPN 1111 DM yang termaktub di PER-10/PJ/2013.

Tabel 4 - Format SPT Masa PPN 1111 DM

\begin{tabular}{|c|c|}
\hline Narasumber & Pendapat \\
\hline $\begin{array}{l}\text { Ilham } \\
\text { (Pelaksana } \\
\text { Direktorat } \\
\text { Peraturan } \\
\text { Perpajakan I) }\end{array}$ & $\begin{array}{l}\text { SPT } 1111 \quad \text { DM } \\
\text { mengakomodir PKP } \begin{array}{r}\text { yang } \\
\text { menggunakan }\end{array} \text { pedoman } \\
\text { penghitungan pengkreditan Pajak } \\
\text { Masukan. Memang disini bedanya } \\
\text { lebih simple karena tujuannya } \\
\text { untuk memberi kemudahan. }\end{array}$ \\
\hline $\begin{array}{l}\text { Tn ABC } \\
\text { (Akademisi, } \\
\text { Peneliti, dan } \\
\text { Praktisi } \\
\text { Perpajakan }\end{array}$ & $\begin{array}{l}\text { Karena di bagian induk harus } \\
\text { menghitung total barang dan total } \\
\text { jasa jadi tidak fair, seolah-olah } \\
\text { dalam SPT } 1111 \text { DM mereka } \\
\text { dijatuhi hukuman oleh negara } \\
\text { karena tetap memperhitungkan } \\
\text { PK-nya menjadi atas seluruh } \\
\text { barang. }\end{array}$ \\
\hline & \\
\hline $\begin{array}{l}\text { Rachmad } \\
\text { (Dosen } \\
\text { Politeknik } \\
\text { Keuangan } \\
\text { Negara STAN) }\end{array}$ & $\begin{array}{l}\text { Seharusnya SPT } 1111 \text { DM itu lebih } \\
\text { sederhana dan tetap tidak } \\
\text { melupakan apa yang ada di SPT } \\
\text { 1111. Formatnya harus dibikin } \\
\text { detail dan dibuat sebuah pilihan. }\end{array}$ \\
\hline
\end{tabular}


Sumber: Diolah dari hasil wawancara

Penggunaan SPT Masa PPN 1111 DM memberikan dampak positif bagi PKP dari sisi administratif dan beban pajak, keuntungan tersebut antara lain PKP memperoleh kesederhanaan dan kemudahan dalam hal pengisian SPT dan penghitungan pajak terutang, serta mendapatkan pengkreditan Pajak Masukan yang lebih besar bagi PKP yang memiliki Pajak Masukan kecil (Hasra, 2018). Bapak Ilham memiliki pendapat yang sama dengan mengatakan bahwa SPT masa PPN 1111 DM digunakan untuk mengakomodasi PKP yang menggunakan Pedoman Penghitungan Pengkreditan Pajak Masukan yang mana PKP tersebut merupakan PKP baru yang masih belajar dan memerlukan edukasi lebih banyak untuk menjalankan kewajibannya sebagai PKP, oleh karena itu format di dalam SPT Masa PPN 1111 DM dibuat lebih sederhana dibandingkan SPT Masa PPN lainnya.

Dilihat dari sisi penghitungan normal Pajak Masukan dan Pajak Keluaran atau Mekanisme Umum, Pajak Masukan dihitung dari jumlah perolehan Barang Kena Pajak dan/atau Jasa Kena Pajak, sedangkan Pajak Keluaran dihitung dari jumlah penyerahan Barang Kena Pajak dan/atau Jasa Kena Pajak, baik Pajak Masukan dan Pajak Keluaran masing-masing dihitung menggunakan tarif $10 \%$. Mekanisme yang digunakan di SPT Masa PPN 1111 DM ini cukup unik karena tidak terdapat komponen Pajak Masukan yang dilaporkan dari kegiatan pembelian atau perolehan yang dilakukan PKP, tetapi menggunakan sebagian persentase dari Pajak Keluaran sehingga PKP yang menggunakan SPT Masa PPN 1111 DM hanya perlu melaporkan penyerahan dan retur penjualan saja (Ilham, 2021).

Di sisi lain, kesederhanaan yang diberikan Direktorat Jenderal Pajak terkait format SPT Masa PPN 1111 DM juga memberikan sisi negatif, yaitu dapat memunculkan indikasi kesalahan penghitungan atas penyerahan barang dan jasa yang tertera di kolom bagian induk. Kesalahan penghitungan yang timbul akan mendistorsi keadilan bagi PKP yang menggunakan Pedoman Penghitungan Pengkreditan Pajak Masukan. Berikut merupakan kolom pengisian penyerahan barang dan jasa yang harus diisi PKP sebagai dasar penghitungan Pajak Keluaran.

Dari gambar di atas dapat disimpulkan bahwa PKP harus mencantumkan seluruh penyerahan barang dan/atau jasa, hal tersebut didukung juga dengan penjelasan pada tata cara pengisian SPT Masa PPN 1111 DM yang mencantumkan seluruh penyerahan barang atau jasa. Seluruh penyerahan tersebut meliputi ekspor, PPN yang harus dipungut sendiri, PPN yang dipungut oleh pemungut, tidak dipungut PPN, dibebaskan dari PPN, serta penyerahan yang tidak dipungut PPN. Hal ini dikarenakan pada kolom Penyerahan Barang dan Jasa tidak terdapat pemisahan kolom penyerahan seperti format SPT Masa PPN 1111. Ketika PKP mencantumkan seluruh penyerahan baik yang dikenakan pajak maupun tidak dikenakan pajak dalam jumlah penyerahan barang dan jasa, akan menimbulkan kekeliruan karena tidak sesuai dengan prinsip dasar UU PPN.

Dalam format tersebut penulisan Penyerahan Barang dan Penyerahan Jasa juga tidak disertai penjelasan yang spesifik, oleh karena itu Wijaya \& Chandika (2020) memberikan saran untuk kolom Penyerahan Barang dan Penyerahan Jasa diberikan penekanan menjadi Penyerahan Barang Kena Pajak pada kolom I.A dan Penyerahan Jasa Kena Pajak pada kolom I.B. Pada kolom Penyerahan Barang dan Jasa pada SPT Masa PPN 1111 DM tidak disediakan kolomkolom terpisah layaknya format yang ada di dalam SPT Masa PPN 1111, meskipun tidak dijelaskan secara spesifik dalam formulir SPT Masa PPN 1111 DM untuk mengisi jumlah penyerahan guna menghitung Pajak Keluaran hanya atas penyerahan yang terutang PPN saja (Ilham, 2021).

Tn ABC dan Bapak Rachmad memberikan pendapat bahwa seharusnya format Penyerahan Barang dan Jasa pada SPT Masa PPN 1111 DM dibuat pengoloman secara terpisah dan mendetail agar PKP lebih mudah untuk mengisi jumlah transaksi penyerahan sehingga dapat diketahui secara jelas mana penyerahan yang terutang pajak, tidak terutang pajak, dan dipungut oleh pemungut PPN. Adanya pemisahan kolom juga memberikan kemudahan bagi PKP terkait jumlah penyerahan yang digunakan untuk dasar pengenaan pajak, yaitu mengambil dari formula penyerahan Barang Kena Pajak dan Jasa Kena Pajak yang dipungut sendiri.

Mengacu pada format SPT Masa PPN 1111 DM dapat disimpulkan bahwa PKP harus mencantumkan seluruh penyerahan barang dan/atau jasa, hal tersebut didukung juga dengan penjelasan pada tata cara pengisian SPT Masa PPN 1111 DM yang mencantumkan seluruh penyerahan barang atau jasa. Seluruh penyerahan tersebut meliputi ekspor, PPN yang harus dipungut sendiri, PPN yang dipungut oleh pemungut, tidak dipungut PPN, dibebaskan dari PPN, serta penyerahan yang tidak dipungut PPN. Hal ini dikarenakan pada kolom Penyerahan Barang dan Jasa tidak terdapat pemisahan kolom penyerahan seperti format SPT Masa PPN 1111. Ketika PKP mencantumkan seluruh penyerahan baik yang dikenakan pajak maupun tidak dikenakan pajak dalam jumlah penyerahan barang dan jasa, akan menimbulkan kekeliruan karena tidak sesuai dengan prinsip dasar UU PPN.

Dalam format tersebut penulisan Penyerahan Barang dan Penyerahan Jasa juga tidak disertai penjelasan yang spesifik, oleh karena itu Wijaya \& Chandika (2020) memberikan saran untuk kolom Penyerahan Barang dan Penyerahan Jasa diberikan penekanan menjadi Penyerahan Barang Kena Pajak pada kolom I.A dan Penyerahan Jasa Kena Pajak pada kolom I.B. Pada kolom Penyerahan Barang dan Jasa pada SPT Masa PPN 1111 DM tidak disediakan kolomkolom terpisah layaknya format yang ada di dalam SPT Masa PPN 1111, meskipun tidak dijelaskan secara 
spesifik dalam formulir SPT Masa PPN 1111 DM untuk mengisi jumlah penyerahan guna menghitung Pajak Keluaran hanya atas penyerahan yang terutang PPN saja (Ilham, 2021).

Tn ABC dan Bapak Rachmad memberikan pendapat bahwa seharusnya format Penyerahan Barang dan Jasa pada SPT Masa PPN 1111 DM dibuat pengoloman secara terpisah dan mendetail agar PKP lebih mudah untuk mengisi jumlah transaksi penyerahan sehingga dapat diketahui secara jelas mana penyerahan yang terutang pajak, tidak terutang pajak, dan dipungut oleh pemungut PPN. Adanya pemisahan kolom juga memberikan kemudahan bagi PKP terkait jumlah penyerahan yang digunakan untuk dasar pengenaan pajak, yaitu mengambil dari formula penyerahan Barang Kena Pajak dan Jasa Kena Pajak yang dipungut sendiri.

Apabila format penyerahan tidak diuraikan secara terpisah, pengguna SPT Masa PPN 1111 DM dapat mengalami kerugian ketika bertransaksi dengan pemungut, Bapak Rachmad memberikan ilustrasi mengenai penyerahan yang dilakukan PKP dengan pemungut. Dari PKP yang dipungut sebesar 10 juta berasal dari penghitungan dari sisi pemungut yaitu 10\% dari jumlah penyerahan. Dengan demikian, PKP menanggung pajak dua kali, hal ini lah yang membuat PKP pengguna deemed Pajak Masukan tidak berkembang.

Bapak Ilham mengatakan bahwa terkait kesederhanaan format SPT Masa PPN 1111 DM, pihak Direktorat Jenderal Pajak berusaha memberikan informasi dan edukasi kepada PKP bahwa meskipun pengadministrasian SPT tersebut terlihat mudah, PKP dituntut untuk dapat membedakan penyerahan barang dan jasa yang terutang dan tidak terutang pajak agar nantinya ketika PKP tersebut sudah berkembang dan berkewajiban menggunakan Mekanisme Umum di SPT Masa PPN 1111 tidak mengalami kesulitan karena sudah memahami dasar penghitungan Pajak Masukan dan Pajak Keluaran.

Mengingat PKP yang menggunakan Pedoman Pengkreditan Pajak Masukan salah satunya adalah penjual kendaraan bermotor bekas secara eceran, untuk melaksanakan kewajiban melaporkan SPT Masa PPN 1111 DM tentu tidak sulit karena penyerahan yang dilakukan hanya atas satu jenis barang yaitu kendaraan bermotor yang merupakan Barang Kena Pajak. Lain halnya bagi PKP yang menggunakan deemed Pajak Masukan dengan kriteria jumlah peredaran usaha tertentu, PKP yang memenuhi kriteria tersebut sering kali adalah pelaku usaha kecil yaitu UMKM. Meskipun di era ini teknologi sudah berkembang dan didukung dengan keterbukaan informasi, tidak semua UMKM memiliki akses untuk mendapatkan informasi dengan mudah, sangat disayangkan apabila PKP UMKM tidak memiliki pengetahuan yang layak terkait PPN sehingga mengalami kerugian usaha akibat kesalahan penghitungan PPN terutang.
Bapak Ilham mengatakan bahwa ketika pelaku usaha sudah dikukuhkan sebagai PKP meskipun pelaku usaha kecil sekalipun, PKP tersebut pasti memahami kewajibannya dalam pengisian SPT Masa PPN 1111 DM. Selain itu, Direktorat Jenderal Pajak juga memberikan program khusus BDS (Business Development System) bagi UMKM.

Program BDS merupakan salah satu upaya yang dilakukan untuk mendukung dan mengembangkan usaha UMKM dari segala aspek, mulai dari kewajiban pembayaran perpajakan, tips dan trik meningkatkan omzet penjualan, mendapatkan informasi mengenai pemasaran usaha, serta literasi dan edukasi perpajakan bagi PKP (Ilham, 2021). Kebijakan tersebut serupa dengan strategi yang dilakukan oleh SII (Servicio de Impuestos Internos) untuk mempromosikan pemenuhan kewajiban pajak tepat waktu dengan bantuan dan dukungan dari sejumlah bisnis asosiasi, inisiatif yang dilakukan memungkinkan asosiasi untuk melakukan komunikasi langsung dengan SII untuk meminta pelatihan dan dukungan khusus, mencari jawaban terkait masalah perpajakan umum, membantu dalam mendeteksi ketidakpatuhan, serta solusi kolaboratif (OECD, 2019).

Menurut penulis, aspek penting yang perlu diperbaiki pada SPT Masa PPN 1111 DM adalah format Penyerahan Barang dan Jasa diberikan pilihan dan disediakan kolom-kolom yang memisahkan berbagai jenis penyerahan untuk menghindari kesalahan penghitungan. Terlebih lagi, penyamaan format SPT Masa PPN 1111 DM dengan SPT Masa PPN 1111 pada kolom penyerahan barang dan jasa tidak akan menimbulkan perbedaan jumlah pajak keluaran karena formatnya yang lebih terstruktur sehingga mempermudah PKP. Menyusul dengan adanya perubahan UU PPN di UU Cipta Kerja sebaiknya Direktorat Jenderal Pajak juga mempertimbangkan perubahan format dan isi SPT Masa PPN 1111 DM serta memberikan penjelasan yang lebih tepat terkait pengisian kolom Penyerahan Barang dan Jasa agar PKP memperoleh kejelasan regulasi dan dapat melaksanakan kewajibannya sebagai PKP tanpa terbebani oleh pajak.

\subsection{Strategi Relaksasi Pengkreditan Pajak Masukan terhadap Sektor Perpajakan Indonesia}

Besley and Persson (2011, 2013, 2014a, 2014b, dikutip dalam Gaspar et al., 2016) menyatakan bahwa negara membutuhkan investasi berikut untuk dapat berfungsi secara efektif:

(a) Kapasitas fiskal, dengan meningkatkan pengumpulan pajak terutama pajak berbasis luas melalui pajak yang pelaksanaannya lebih kuat;

(b) Kapasitas hukum, yang mengacu pada regulasi pendukung pasar, penegakan kontrak, dan perlindungan hak milik; dan

(c) Kapasitas kolektif, dengan meningkatkan pasar. Pemberian hak Relaksasi Pengkreditan Pajak Masukan dan ketentuan di dalamnya tentu 
menyesuaikan kondisi perekonomian negara saat ini. Otoritas pajak menilai sejumlah data yang diperoleh pada tahun-tahun sebelumnya terkait kontribusi pelaku usaha terhadap penerimaan negara. Dari penilaian tersebut, pemerintah dapat mengetahui strategi apa yang perlu dilakukan untuk memperoleh penerimaan pajak secara optimal melalui kepatuhan wajib pajak, yakni pemberlakuan Relaksasi Pengkreditan Pajak Masukan (Bapak Ilham, Pelaksana Direktorat Peraturan Perpajakan I).

Perubahan peraturan Pajak Pertambahan Nilai semata-mata untuk memberikan keadilan dan kemudahan bagi PKP tanpa terbebani oleh pengenaan pajak karena kepatuhan wajib pajak merupakan aspek penting yang harus ada untuk mendukung sistem perpajakan Indonesia. Seiring dengan meningkatnya kepatuhan wajib pajak dan dimilikinya kesadaran diri untuk melaksanakan kewajiban sebagai wajib pajak akan berdampak positif ke penerimaan negara yang mana masyarakat juga memperoleh keuntungan dan kesejahteraan secara tidak langsung.

Mengingat banyak diberikannya keringanan pajak dalam Relaksasi Pengkreditan Pajak Masukan, timbul pertanyaan apakah ada kemungkinan DJP mengalami kerugian yang disebabkan banyaknya insentif pajak dalam UU Cipta Kerja contohnya terkait pengusaha sebelum PKP yang hanya membayar PPN sebesar $2 \%$ yang mana persentase tersebut jauh dari tarif normal PPN yang seharusnya dibayar PKP dengan peredaran bruto dalam satu tahun melebihi 4,8 miliar rupiah.

DJP memberikan keringanan bagi wajib pajak melalui pembayaran pajak hanya sebesar $2 \%$ untuk memberikan keringanan di awal pengukuhan PKP, hal tersebut ditujukan agar pengusaha secara sukarela dapat melaksanakan kewajibannya sebagai PKP (Bapak Ilham, Pelaksana Direktorat Peraturan Perpajakan I).

OECD (2004, dikutip dalam Pohan, 2016) menjelaskan perilaku kepatuhan dari wajib pajak dilihat dari dua pendekatan, yaitu faktor ekonomi dan faktor perilaku. Salah satu faktor dari perspektif ekonomi adalah beban keuangan wajib pajak, ketika wajib pajak dapat memenuhi kewajibannya dengan kondisi keuangannya, maka wajib pajak akan bersedia membayar pajak. Sedangkan apabila wajib pajak mengalami likuidasi atau kebangkrutan yang menyebabkan keuangannya menurun, wajib pajak akan mengambil celah untuk menghindari pajak. Sementara salah satu contoh faktor perilaku adalah adanya asumsi ketidakadilan, hal ini digambarkan mengenai wajib pajak akan bertindak tidak patuh apabila sistem perpajakan dan pengalaman yang dirasakan saat membayar pajak cenderung mencerminkan ketidakadilan.

Menurut Bapak Rachmad, strategi relaksasi bagi investasi cukup tepat apabila dilihat dari kacamata politik. Kebijakan Relaksasi Pengkreditan Pajak Masukan juga dapat turut membantu menghilangkan stigma negatif dari masyarakat terkait pajak karena diberikannya kemudahan investasi dan berusaha di Indonesia tanpa terbebani oleh pajak. Hal tersebut didukung juga dengan pernyataan $T n A B C$ bahwa banyak pelaku usaha yang takut akan pajak karena tidak sedikit pengusaha yang bangkrut akibat pajak sehingga para wajib pajak berupaya untuk memanfaatkan peluang untuk menghindari pajak. Oleh karena itu, dengan adanya Relaksasi Pengkreditan Pajak Masukan dapat memberikan keringanan bagi wajib pajak agar kegiatan usahanya tetap berkembang.

Tren Pajak Pertambahan Nilai dikenal akan semakin meningkat, saat ini dilakukannya perubahan peraturan PPN masih akan terus berlanjut. Dengan terus berkembangnya regulasi perpajakan dalam rangka meningkatkan kepatuhan wajib pajak $\mathrm{Tn} A B C$ memberikan pendapatnya dengan mengaitkan kepatuhan wajib pajak terhadap tax ratio Indonesia yang diharapkan dapat mencapai $21 \%$ sebagaimana penelitian IMF jika wajib pajak patuh ( $T n$ ABC, Akademisi, Peneliti, dan Praktisi Perpajakan).

Di samping itu, dalam pertumbuhan ekonomi endogen, sistem perpajakan yang dirancang dengan baik juga dapat meminimalkan efisiensi kerugian yang dikenakan oleh pajak, bahkan dapat meningkatkan tingkat pertumbuhan PDB (Barro \& Martin, 1992, dikutip dalam Gaspar et al., 2016).

Bapak Ilham berpendapat pengadaan Relaksasi Pengkreditan Pajak Masukan belum dapat diketahui pasti apakah merupakan strategi yang tepat dan sudah memberikan kontribusi yang signifikan bagi sektor perpajakan karena masih diperlukan beberapa indikator yang mengukur tingkat ketepatan. Untuk mengukur tingkat ketepatan tersebut perlu perbandingan antara tujuan awal dengan apa yang sudah dicapai. Untuk mengukurnya membutuhkan data terkait keberhasilan peningkatan kepatuhan wajib pajak, peningkatan penerimaan pajak, hingga dampak perkembangan usaha PKP setelah diberikannya Relaksasi Pengkreditan Pajak Masukan. Tentunya saat ini belum dapat diukur karena perbandingan yang ada belum cukup signifikan akibat time series yang cukup lama.

Dari pernyataan ketiga narasumber dapat disimpulkan bahwa banyak yang memberikan respons positif terhadap Relaksasi Pengkreditan Pajak Masukan meskipun masih terdapat beberapa pihak eksternal yang keberatan. Sementara itu, terkait kemungkinan penurunan penerimaan PPN akibat diberikannya Relaksasi Pengkreditan Pajak Masukan tergantung bagaimana wajib pajak menyikapinya. Apabila wajib pajak patuh tentu akan memberikan kepastian bahwa Relaksasi Pengkreditan Pajak Masukan berhasil mendongkrak penerimaan PPN semakin meningkat.

Hak Relaksasi Pengkreditan Pajak Masukan yang diberikan kepada para pelaku usaha digambarkan sebagai kail untuk memicu wajib pajak agar patuh sehingga berdampak ke peningkatan penerimaan pajak dan tax ratio Indonesia. Secara keseluruhan, strategi 
Relaksasi Pengkreditan Pajak Masukan merupakan kebijakan negara yang tepat apabila dilihat dari sisi keadilan urusan perpajakan, selain itu Relaksasi Pengkreditan Pajak Masukan sifatnya untuk ekstensifikasi karena di dalam peraturan tersebut tidak mengubah ketentuan dan konstelasi yang lama, sehingga tidak akan mengganggu penerimaan PPN (ABC, 2021).

\section{KESIMPULAN DAN SARAN}

Berdasarkan hasil pembahasan, penulis menarik kesimpulan sebagai berikut.

1. Pengusaha yang ingin menggunakan hak mengkreditkan Pajak Masukan sebelum pengusaha dikukuhkan sebagai PKP harus teradministrasi di Direktorat Jenderal Pajak dengan diwajibkan untuk dikukuhkan sebagai PKP terlebih dahulu secara official assessment ataupun self assessment. PKP yang dimaksud menggunakan deemed Pajak Masukan dengan tarif $80 \%$ dari Pajak Keluaran atau setara dengan membayar PPN terutang sebesar $2 \%$ ke kas negara.

2. PMK 74/PMK.03/2010 yang saat ini masih berlaku dianggap sudah tidak relevan lagi dan sebaiknya dilakukan perubahan atau pencabutan. Tarif Pedoman Penghitungan Pengkreditan Pajak Masukan yang ada di UU Cipta Kerja kurang memberikan keadilan bagi PKP yang sudah memilih menggunakan PMK 74/PMK.03/2010 dikarenakan persentase untuk mengkreditkan Pajak Masukan bagi PKP tidak patuh lebih besar dibandingkan PKP patuh.

3. Untuk melakukan Pedoman Penghitungan Pengkreditan Pajak Masukan dapat menggunakan SPT Masa PPN 1111 atau SPT Masa PPN 1111 DM menyesuaikan kondisi dari PKP yang bersangkutan. Pengkreditan Pajak Masukan sebelum pengusaha dikukuhkan sebagai PKP dihitung sejak masa pajak dalam satu tahun buku ketika pengusaha telah memiliki peredaran bruto lebih dari 4,8 miliar dan seharusnya sudah dikukuhkan menjadi PKP hingga masa pajak terakhir tepat sebelum pengusaha tersebut benar-benar dikukuhkan sebagai PKP.

4. Pada dasarnya, format SPT Masa PPN 1111 DM dibedakan dengan SPT Masa PPN 1111 adalah untuk memberikan simplifikasi bagi PKP yang menggunakan Pedoman Pengkreditan Pajak Masukan. Bagian Penyerahan Barang dan Jasa hanya terdiri dari dua kolom yang mempermudah PKP untuk mengisi kolom penyerahan tetapi dalam waktu yang sama menimbulkan multitafsir dalam hal pengisian kolom penyerahan SPT Masa PPN 1111 DM. Di samping itu, beberapa pihak memberikan pendapat bahwa sebaiknya kolom penyerahan SPT Masa PPN 1111 DM disamakan saja dengan kolom penyerahan SPT Masa PPN 1111 agar lebih detail dan mengurangi terjadinya kekeliruan dalam pengisian Pajak Keluaran sebagai Dasar Pengenaan Pajak.

5. Strategi Relaksasi Pengkreditan Pajak Masukan dilakukan untuk mencapai kepatuhan sukarela dan meningkatkan kepercayaan masyarakat terhadap administrasi perpajakan.

\section{DAFTAR PUSTAKA}

ABC, T. (2021). (I. Awwalia, Interviewer)

Anggraeni, R., \& Rachman, C. I. (2020). Omnibus Law in Indonesia: Is That the Right Strategy? 140, 180182.

Antic, D. (2014). Effieciency of Single-Rate and BroadBased VAT System: The Case of Bosnia.

Barro, R. J., \& Martin, X. S.-I. (1992). Public Finance Models of Economic Growth. The Review of Economic Studies.

Besley, T., \& Persson, T. (2013). Taxation and Development.

Black, H. C. (1968). Black's Laws Dictionary. St. Paul, Minn: West Publishing Co.

Buchanan, S. (2019). Educating Future Taxpayers: Teaching taxes to Youth in Canada. Tax Administration 2019 : Comparative Information on OECD and Other Advanced and Emerging Economies.

Cahyasari, W. F. (2018, July 13). Empat Belas Juli, Awal Sejarah Reformasi Perpajakan. Retrieved from Direktorat Jenderal Pajak: https://www.pajak.go.id/artikel/empat-belasjuli-awal-sejarah-reformasi-perpajakan

Center for Indonesia Taxation Analysis. (2020). UU Cipta Kerja Klaster Perpajakan. Retrieved from https://cfoclubindonesia.co.id/wpcontent/uploads/2020/11/Summary-UUCipta-Kerja-Klaster-Perpajakan-_-by-CITA.pdf

CNN Indonesia. (2020, Juli 13). Pelaku UMKM Takut Berurusan dengan Pajak. Retrieved from https://www.cnnindonesia.com/ekonomi/202 00713131817-92-524008/pelaku-umkmtakut-berurusan-dengan-pajak

Cnossen, S. (1992). Key questions in considering a valueadded tax for central and Eastern. International Monetary Fund Staff Papers.

Darussalam, Septriadi, D., \& Dhora, K. A. (2018). Konsep dan Studi Komparasi Pajak Pertambahan Nilai. DDTC.

Devano, S., \& Rahayu, S. K. (2006). Perpajakan, Konsep, Teori dan Isu. Jakarta: Kencana.

Direktorat Jenderal Pajak. (n.d.). Reformasi Perpajakan. Retrieved from https://www.pajak.go.id/reformasiperpajakan

Ebrill, L., Keen, M., Bodin, J. P., \& Summers, V. (2001). The Modern VAT. Washington D.C: International Monetary Fund. 
Gaspar, V., Jaramillo, L., \& Wingender, P. (2016). Tax Capacity and Growth: Is There a Tipping Point? IMF Working Papers.

Gillis, M. ( 1989). Toward a Taxonomy for Tax Reform, dalam Gillis Malcom. Tax Reform in Developing Countries. London: Duke University Press.

Hamid, J. (2019). Hubungan Penerimaan PPN dengan Tingkat Konsumsi Masyarakat. Retrieved from Kemenkeu.go.id:

https://www.kemenkeu.go.id/publikasi/artike I-dan-opini/hubungan-penerimaan-ppn-dantingkat-konsumsi-masyarakat/

Haryanti, M. D., \& Hidayah, I. (2018, Juli 24). Potret UMKM Indonesia: Si Kecil yang Berperan Besar. Retrieved from UKM Indonesia: https://www.ukmindonesia.id/bacaartikel/62\#: :text=Usaha\%20Mikro\%20hanya \%20memiliki\%20rata,sekitar\%20Rp99\%20juta \%20per\%20hari.

Hasra, N. (2018). Tinjauan Penerapan Formulis Surat Pemberitahuan Masa Pajak Pertambahan Nilai 1111 DM Berdasarkan Peraturan Direktur Jenderal Pajak Nomor PER-10/PJ/2013.

Idris, M. (2020, 10 05). Mengenal Apa Itu Omnibus Law RUU Cipta Kerja dan Isi Lengkapnya. Retrieved from

Kompas.com: https://money.kompas.com/read/2020/10/05 /102200626/mengenal-apa-itu-omnibus-lawruu-cipta-kerja-dan-isi-lengkapnya?page=all

Ikhsan, M., Trialdi, L., \& Syahrial, S. (2005). Indonesia's new tax reform: Potential and direction. Journal of Asian Economics.

Ilham. (2021). (Izma, Interviewer)

Jha, R. (2010). Modern Public Economics (2nd ed.).

Kementerian Keuangan. (2010a). Peraturan Menteri Keuangan Nomor 68/PMK.03/2010 tentang Batasan Pengusaha Kecil Pajak Pertambahan Nilai. Jakarta: JDIH Kemenkeu. Retrieved from https://jdih.kemenkeu.go.id/fullText/2010/68 PMK.03 2010Per.HTM

Kementerian Keuangan. (2010b). Peraturan Menteri Keuangan Nomor 74/PMK.03/2010 tentang Pedoman Pengkreditan Pajak Masukan Bagi Pengusaha Kena Pajak yang Mempunyai Peredaran Usaha Tidak Melebihi Jumlah Tertentu. Jakarta: JDIH Kemenkeu. Retrieved from

https://jdih.kemenkeu.go.id/fullText/2010/74 PMK.03 2010Per.HTM

Kementerian Keuangan. (2010c). Peraturan Menteri Keuangan Nomor 79/PMK.03/2010 tentang Pedoman Penghitungan Pengkreditan Pajak Masukan bagi Pengusaha Kena Pajak yang Melakukan Kegiatan Usaha Tertentu. Jakarta: JDIH Kemenkeu. Retrieved from https://jdih.kemenkeu.go.id/fullText/2010/79 PMK.03 2010Per.HTM
Kementerian Keuangan. (2012a). Peraturan Direktur Jenderal Pajak Nomor PER-24/PJ/2012 tentang Bentuk, Ukuran, Tata Cara Penglsian Keterangan, Prosedur Pemberitahuan dalam Rangka Pembuatan, Tata Cara Pembetulan atau Penggantian, dan Tata Cara Pembatalan Faktur Pajak. Jakarta: Ortax. Retrieved from https://www.ortax.org/ortax/?mod=aturan\&p age $=$ show $\& i d=15137$

Kementerian Keuangan. (2012b). Laporan Tahunan DJP 2012.

Kementerian Keuangan. (2013a). Peraturan Direktur Jenderal Pajak Nomor PER-10/PJ/2013 tentang Bentuk, Isi, dan Tata Cara Pengisian serta Penyampaian SPT Masa PPN bagi Pengusaha Kena Pajak yang Menggunakan Pedoman Penghitungan Pengkreditan Pajak Masukan. Jakarta. Retrieved from https://perpajakan.ddtc.co.id/peraturanpajak/read/peraturan-direktur-jenderal-pajakper-10pj2013

Kementerian Keuangan. (2013b). Peraturan Direktur Jenderal Pajak Nomor PER-11 /PJ/2013 tentang Perubahan atas Peraturan Direktur Jenderal Pajak Nomor PER-44/PJ/2010 tentang Bentuk, Isi, dan Tata Cara Pengisian serta Penyampaian Surat Pemberitahuan Masa Pajak Pertambahan Nilai. Jakarta: Ortax. Retrieved from https://www.ortax.org/ortax/?mod=aturan\&p age=show\&id $=15261$

Kementerian Keuangan. (2013c). Peraturan Menteri Keuangan Nomor 197/PMK.03/2013 tentang Perubahan atas Peraturan Menteri Keuangan Nomor 68/PMK.03/2010 tentang Batasan Pengusaha Kecil Pajak Pertambahan Nilai. Jakarta: JDIH Kemenkeu. Retrieved from https://jdih.kemenkeu.go.id/fulltext/2013/19 7 PMK.03 2013Per.HTM

Kementerian Keuangan. (2014). Peraturan Menteri Keuangan Nomor 30/PMK.03/2014 tentang Pajak Pertambahan Nilai atas Penyerahan Emas Perhiasan. Jakarta: JDIH Kemenkeu. Retrieved from https://jdih.kemenkeu.go.id/fulltext/2014/30 PMK.03 2014Per.HTM

Kementerian Keuangan. (2015). Surat Edaran Direktur Jenderal Pajak Nomor SE - 02/PJ/2015 tentang Penegasan atas Pelaksanaan Pasal 31E Ayat (1) Undang-Undang Pajak Penghasilan. Jakarta.

Kementerian Keuangan. (2019). Laporan Tahunan DJP 2019. Jakarta.

Kementerian Keuangan. (2020a, Agustus 24). UMKM Bangkit, Ekonomi Indonesia Terungkit. Retrieved from https://www.djkn.kemenkeu.go.id/artikel/bac a/13317/UMKM-Bangkit-Ekonomi-IndonesiaTerungkit.html 
Kementerian Keuangan. (2020b). Ini Urgensi Perlunya Reformasi Perpajakan. Retrieved from https://www.kemenkeu.go.id/publikasi/berita /ini-urgensi-perlunya-reformasi-perpajakan/

Kementerian Keuangan. (2020c). Laporan Kinerja DJP 2020.

Kementerian Keuangan. (2021). Peraturan Menteri Keuangan Nomor 18/PMK.03/2021 tentang Pelaksanaan Undang-Undang Nomor 11 Tahun 2020 tentang Cipta Kerja di Bidang Pajak Penghasilan, Pajak Pertambahan Nilai dan Pajak Penjualan atas Barang Mewah, serta Ketentuan Umum Perpajakan. Jakarta: JDIH Kemenkeu. Retrieved from https://jdih.kemenkeu.go.id/download/39fdb 2fc-1736-4ebb-80f5d257f75df0b5/18 PMK.03 2021Per.pdf

Kementerian Keuangan. (n.d.). Data Statistik DJP.

Kuncoro, A. R. (2015, Mei 18). Prinsip-Prinsip Pemajakan. Retrieved from Forum Pajak Indonesia: https://forumpajak.org/prinsipprinsip-pemajakan/

Kurniati, D. (2021). Soal Dampak Ekonomi Reformasi Perpajakan, Begini Penegasan Kemenkeu. Retrieved from DDTC News: https://news.ddtc.co.id/soal-dampakekonomi-reformasi-perpajakan-beginipenegasan-kemenkeu-30345

Laucereno, S. F. (2018, Agustus 6). Sri Mulyani: Kita Negara Paling Kompleks Aturan Perpajakannya. Retrieved from detikfinance: https://finance.detik.com/berita-ekonomibisnis/d-4153099/sri-mulyani-kita-negarapaling-kompleks-aturan-perpajakannya

Le, T. M. (2003). Value Added Taxation: Mechanism, Design, and Policy Issues.

Lovely Professional University. (2012). Indirect Tax Laws.

McNulty, J. K. (2000). Flat Tax, Consumption Tax, Consumption-Type Income Tax Proposals in the United States: A Tax Policy Discussion of Fundamental Tax Reform. Berkeley Law Scholarship Repository.

Mengenal Omnibus Law - Latar Belakang dan Tujuan. (2020). Retrieved from https://gajimu.com/pekerjaanyanglayak/omnibus-law-uu-ciptakerja/omnibus-law-uu-cipta-kerja

Nurhanisah, Y., \& Devina, C. (2020). Menelusuri Fakta Omnibus Law. Retrieved from http://indonesiabaik.id/infografis/menelusurifakta-omnibuslaw\#: :text=Indonesia\%20sendiri\%20pernah\% 20melakukan\%20omnibus,Kepentingan\%20Pe rpajakan\%20menjadi\%20Undang\%2DUndang.

OECD. (2004). Compliance Risk Management: Managing and Improving Tax. Centre For Tax Policy and Administration, 37.
OECD. (2011). Consumption Tax Trends 2010: VAT/GST and Excise Rates, Trends and Administration Issues. Paris: OECD publishing.

OECD. (2017). International VAT/GST Guidelines. Paris: OECD Publishing.

OECD. (2018). OECD Economic Surveys : Indonesia.

OECD. (2019). Tax Administration 2019 : Comparative Information on OECD and Other Advanced and Emerging Economies.

Pohan, C. A. (2016). Pajak Pertambahan Nilai : Teori, Konsep, dan Aplikasi PPN. Jakarta: PT Gramedia Pustaka Utama.

Prabowo, A. S., Triputra, A. N., Junaidi, Y., \& Purwoleksono, D. E. (2020). Politik Hukum Omnibus Law di Indonesia. Jurnal Pamator.

Prastowo, Y. (2019, Desember 4). Omnibus Law dan Reformasi Pajak. Retrieved from Center for Indonesia Taxation Analysis: https://cita.or.id/omnibus-law-dan-reformasipajak/

Rachmad. (2021). (Izma, Interviewer)

Rahayu, S. K. (2010). Perpajakan Indonesia : Konsep dan Aspek Formal. Yogyakarta: Graha Ilmu.

Republik Indonesia. (2007). Undang-Undang Nomor 28 Tahun 2007 tentang Perubahan Ketiga atas Undang-Undang Nomor 6 Tahun 1983 tentang Ketentuan Umum dan Tata Cara Perpajakan. Jakarta. Retrieved from https://pajak.go.id/index.php/id/undangundang-nomor-28-tahun-2007

Republik Indonesia. (2008). Undang-Undang Republik Indonesia Nomor 36 Tahun 2008 Tentang Perubahan Keempat atas Undang Undang Nomor 7 Tahun 1983 Tentang Pajak Penghasilan. Jakarta. Retrieved from https://www.pajak.go.id/id/undang-undangnomor-36-tahun-2008

Republik Indonesia. (2009). Undang-Undang Nomor 42 Tahun 2009 tentang Perubahan Ketiga Atas Undang-Undang Nomor 8 Tahun 1983 tentang Pajak Pertambahan Nilai Barang dan Jasa dan Pajak Penjualan Atas Barang Mewah. Jakarta: JDIH Kemenkeu. Retrieved from https://jdih.kemenkeu.go.id/fullText/2009/42 TAHUN2009UU.HTM

Republik Indonesia. (2020). Undang-Undang No. 11 Tahun 2020 tentang Cipta Kerja. Jakarta. Retrieved from https://peraturan.bpk.go.id/Home/Details/14 9750/uu-no-11-tahun-2020

Rezkisari, I. (2020, Oktober 12). Omnibus Law UU Ciptaker dan Tujuan Kesejahteraan Masyarakat. Retrieved from https://republika.co.id/berita/qi2s4m328/om nibus-law-uu-ciptaker-dan-tujuankesejahteraan-masyarakat

Rogers, J., \& Glabush. (2015). IBFD International Tax Glossary, 7th Edition. 
Savage, J. (2019). Measuring impacts on the taxpayer's perception of administrative burdens dalam OECD Tax Administration 2019 Comparative Information on OECD and Other Advanced and Emerging Economies.

Schenk, A., \& Oldman, O. (2007). Value Added Tax: A Comparative Approach. United Kingdom: Cambridge University Press.

Sukardji, U. (2015). Pokok-Pokok PPN (Pajak Pertambah Nilai) Indonesia.

Suwiknyo, E. (2019, April 13). Cek Fakta : Rasio Pajak Indonesia Disebut Paling Rendah, Ini Datanya. Retrieved from Bisnis.com: https://ekonomi.bisnis.com/read/20190413/2 59/911503/cek-fakta-rasio-pajak-indonesiadisebut-paling-rendah-ini-datanya

Tait, A. A. (1988). Value Added Tax International Practice and Problems. Washington D.C.: International Monetary Fund.

Terra, B. J. (1988). Sales Taxation: The Case of Value added Tax in the European Community.

Tim Redaksi Ortax. (2020, Desember 21). Tax Learning : Relaksasi Hak Pengkreditan Pajak Masukan bagi PKP dalam UU Ciptaker. Retrieved from https://www.ortax.org/ortax/?mod=studi\&pa ge $=$ show $\&$ id $=242 \& q=\& h / m=1$

Wijaya, S., \& Arumningtias, D. (2021). Preventing The Potential Tax Avoidance in Government Regulation of The Republic of Indonesia Number 23 of 2018.

Wijaya, S., \& Chandika, M. R. (2020). Pajak Pertambahan Nilai : Implementasi Mekanisme Pedoman Penghitungan Pengkreditan Pajak Masukan. Tim Eduvation.

Williams, D. (1996). Value Added Tax dalam Tax Law Design and Drafting Chapter 6, Value-Added Tax. Washington D.C: International Monetary Funds.

Yuliawati. (2020, Oktober 23). Gemuknya Omnibus Law RI dibandingkan Amerika, Inggris dan Jerman. Retrieved from Katadata.co.id: https://katadata.co.id/yuliawati/berita/5f92a 7d416c60/gemuknya-omnibus-law-ridibandingkan-amerika-inggris-danjerman?_cf_chl_jschl_tk_=2bd05dd885a12 5f5fe8d1aa2a8ea095b7f5984b1-16234835200 AcuYAysjWW5pB8rlYBmYmo5Fiuw5z6SnC_BF rOQ9WdXvdMYYHQZagL-hGVj9iVV 